Ксенија В. Миловановић Прва београдска гимназија
Оригинални научни рад

Примљен: 6. 10. 2017.

Прихваћен: 23. 10. 2017.

\title{
ПОВЕСТ О ПАДУ ЦАРИГРАДА 1453. ГОДИНЕ ПРЕМА СРПСКОМ ПРЕПИСУ ХVII ВЕКА
}

Спис који тематизује освајање Цариграда изворно припада руској књижевности с краја XV или почетка XVI века. Дело је писца Нестора Искандера под називом Повест о турском заузимању Цариграда. У Патријаршијској библиотеци у Београду чува се препис овог списа из последње четвртине седамнаестог века, који је написан на српскословенском језику, полууставним типом ћирилице. У раду су испитане фонетске, морфолошке, лексичке и палеографске особености овог преписа. Циљ није био да се описане појаве представе у синхроној равни, већ је доминантна дијахронијска перспектива. Репрезентативни примери доведени су у везу са прасловенским и старословенским облицима. Посебна пажња посвећена је вокализацији полугласника, која није доследно извршена, као и неправилној дистрибуцији слова јат. У прилогу је дат приређен текст Повести o паду Цариграда 1453. године који припада рукопису Патријаршијске библиотеке број 343.

Кључне речи: Спис о паду Цариграда, Нестор Искандер, историја језика, палеографија, вокализација полугласника.

Повест о заузимању Цариграда је руски састав настао у касном XV или раном XVI веку, а тематизује пад византијске престонице под турску власт. Изворни текст, који није сачуван, очигледно је садржао дело о осни-

*milovanovicksenija@gmail.com 
вању Цариграда 295. године и посебну повест о заузимању Цариграда 1453. године. Ова два композициона дела нису подједнако изазовна за проучавање. Први део, састављен од већ постојећих легенди, осредњег је литерарног значаја. Други, напротив, представља изворно дело и има богатију уметничку и историјску вредност. Велики број догађаја описан је истоветно као у студијама о животу Мехмеда Другог, које је писао византијски историчар Критобулас, а које нису објављиване до 1870. године (Милер 1870). Поред повести о заузимању и оснивању града, многи руски преписи садрже уметнуте епизоде, као што су легенда о имену Византије, списак оријенталних императора или пророчанство Данила Монаха (о руским преписима више у: Унбегаум 1929). Ове епизоде, по свему судећи, нису припадале изворном аутографу, већ су додаване у каснијим преписима. У редакцији архимандрита Леонида композиција је обогаћена и поговором у коме је записано име аутора (Леонид 1886). Међутим, припадност поговора изворном тексту може се довести у питање. Када се упореде различити руски преписи, уочава се да је писар веома често маштовити коаутор, а не пуки преписивач, па је стога тешко реконструисати изворни текст. Архимандрит Леонид, у предговору свог издања, дао је списак до тада познатих верзија преписа у руској традицији. Верзија коју је објавио по његовом мишљењу је најстарија, најцеловитија и најисправнија од свих дотадашњих. Само у овој редакцији даје се одговор у погледу ауторства: списатель же симъ азъ многогрешный и бізаконный Несторь Искиндъръ.

О могућем писцу Нестор-Искандеру из поговора сазнајемо неколико података: да је био руског порекла, али у младости присиљен да прихвати ислам, а затим и да се бори у муслиманским редовима испод зидина Цариграда. Током борби скривао се, желећи да избегне борбу са хришћанима. Међутим, за време опсаде бележио је све што се дешавало у турској војсци, а након заузимања града допуњавао белешке разговарајући са становницима Цариграда. Овај поговор свакако је интересантан, али поставља се питање његове аутентичности. Он се појављује само у једном препису, који управо обилује изузетним инвенцијама преписивача. Проучавајући описе битке, Унбегаум долази на помисао да је аутор током опсаде био унутар зидина града, а не међу турском војском (Унбегаум 1929). Поткрепљење за то налази у запажању да се догађаји унутар града детаљно и тачно описују, док се уочава одређено незнање када се говори о турским активностима ван зидина. Тако, на пример, кључна улога у турској војсци додељује се адмиралу Баитаоглу, кога је након неуспеха у поморској бици 20. априла заменио Хамза бег. Унбегаум претпоставља да је писац био 
међу браниоцима града и зато што је писање о данима који долазе након продора турске војске пуно неправилности: султан тријумфално улази у град једанаестог дана после освајања, становници града настављају битку унутар зидина и после 29. маја итд. Стога Унбегаум изводи хипотезу о писцу-браниоцу, који након упада победничке војске успева да се спасе и побегне једним од ђеновљанских бродова који је на дан великог освајања града умакао из Златног рога. Ова хипотеза, по Унбегаумовом мишљењу, разрешава још једну енигму. Наиме, у свим руским преписима појављују се необични облици властитих именица Ђенова и Јустинијан: Зустунеја и Зиновија/Зеновија. Грчки и латински извори наводе ове именице у облику: Justinianos и Genиа. Једини документ у коме су ова имена написана са иницијалним 3 као и у руским рукописима, јесте Дневник Николе Барбара (Барбаро 1856), у коме се налазе облици Zuan, Zutignan и Zenovexe. Николо је писао венецијанским дијалектом у коме је присутна промена г у 3 испред препалаталних вокала, што одликује дијалекте северне Италије. Руски облици указују на то да је аутор текста био у контакту са Италијанима, што Унбегаума наводи на претпоставку да је аутор након путовања ђеновљанским бродом један период остао у Ђенови. А. Кримски, међутим, сматра поговор аутентичним, и подразумева, не објашњавајући зашто, да је аутор рукописа нашао уточиште у Италији и након тога се вратио у Русију (Кримски 1924).

У досадашњим научним радовима доводило се у питање и порекло изворног текста. Док је општеприхваћено мишљење да повест о заузимању Цариграда припада руској традицији, поједини проучаваоци сматрају да руски текст представља превод грчког оригинала (Унбегаум 1929). Као главни аргумент наводи се велики број хеленизама у тексту. Са друге стране, облици Зустунеј и Зиновија изгледају као доказ против постојања грчког оригинала, јер тешко да би грчки писац у овом облику цитирао два имена која су му морала бити позната. Николаје Јорга, проучавајући румунску верзију рукописа о паду Цариграда, даје аргументе против словенског порекла текста, заступајући тезу о грчком оригиналу (Јорга 1927). Унбегаум сматра да би било илузорно указивати на грчко порекло без јачих аргумената. Такође, он у руским преписима не проналази ни балканизме, на основу којих Мијатовић претпоставља да би аутор изворног текста могао бити српског или бугарског порекла (Мијатовић 1892). Унбергаум се осврће и на српске преписе овог текста, истичући да је нетачна хипотеза Александра Николајевича Пипина о већој старини српских преписа у односу на руске варијанте (Пипин 1858). М. Н. Сперански сматра да сви српски преписи представљају превод руског текста, али не прецизира која је руска варијанта прототип српским текстовима (Сперански 1898). 
Две целине Повести о заузимању Цариграда у српској традицији појављују се као самостални текстови. У домаћој литератури већ су проучавани списи о оснивању и паду Цариграда који припадају Цароставнику манастира Студенице (Јовановић 1994). Предмет овог рада биће повест о заузимању Цариграда која се налази у рукописној збирци Патријаршијске библиотеке у Београду из треће четвртине XVII века. Легенда о оснивању Цариграда не претходи повести о паду византијске престонице нити као фрагмент, нити као засебан спис. Композиција студеничког и патријаршијског преписа готово је истоветна. У оба преписа инкорпорирана је молитва патријарха и свештеног сабора, описано је Константиново безуспешно слање посланика за мир, кроз многе епизоде представљена је беспоштедна борба две војске, и упечатљиво је приказана смрт кнеза Јустинијана, војводе Рагавеја и источног беглер-бега. Немилосрдна борба дочарана је живописним визуелним сликама (густи дим покрива град, крв тече као река, а Турци ходају по мртвим телима као по степеницама), као и аудитивним ефектима (одзвања грмљавина топова и пушака, звекет оружја, вапаји рањених). Аутентичне сцене ратовања указују на писцаучесника, због чега је ово дело довођено у везу са Јаничаровим успоменама Константина Михајловића (Јовановић 1994). У оба преписа о паду Цариграда појављује се мотив страдања због почињених греха, а пропаст града антиципацијски је приказана на небу, двоструким знамењем.

Спис је написан уставним типом писма, са елементима брзописа. Приликом палеографских истраживања приметна је извесна неустаљеност словних облика, која резултира великим бројем морфолошких дублета. Слова су исписивана у четворолинијском систему, при чему су одређени словни облици готово увек интерлинеарни, док други прелазе у доњи односно у горњи међупростор. Поред уставног, интерлинеарног облика, слово а у рукопису има и брзописни облик, који одликује стабло продужено у доњи међупростор, у виду извијене усправне линије. Брзописна варијанта слова в одликује се лучном линијом која се спушта до доње линије реда. Брзописно в писано је двојако: једним потезом, при чему се добијала обла форма, и са четири потеза, при чему се добијала квадратна форма слова, што је у рукопису заступљеније. Брзописна варијанта слова г одликује се продуженим стаблом које прелази у доњи међупростор, док је варијанта слова А знатно упрошћенија у односу на уставну варијанту и има троугласти облик. Поред уобичајеног облика слова $\epsilon$, у рукопису се релативно често јавља и тзв. широко $\epsilon$, оба у искључиво облој форми. Као морфолошки дублет слова $є$, уочљив је и грчки, једнопотезни облик. Слово ж је симетрично у вертикалном пресеку, али је горњи део несра- 
змерно мањи од доњег. Поред овог, основног облика, јавља се и двопотезна варијанта, чије су укрштене линије са десне стране спојене. Слово н јавља се у два облика, као усправна линија изнад које се могу налазити једна или две надредне тачке, и као тропотезна варијанта, која се састоји од две паралелне усправне линије и једном попречном. За слово к карактеристично је да је десни део, који може бити угласт или заобљен, одвојен од стабла, док слово м има брзописну, једнопотезну варијанту, углавном када је натписано. Слово н у овом рукопису писано је истоветно као тропотезно н, па је за њихово разликовање неопходно уважити семантички аспекат речи, с обзиром да палеографских дистинкција нема. Слово т углавном је троного и интерлинеарно. Међутим, јавља се, најчешће при крају речи, позициона варијанта овог слова - високо једноного Т, преузето из грчког минускулног писма. У рукопису се слово ү пише искључиво као лигатура ๖, са два изузетка (оүдарншь 47б, (номог 49б), у којима се појављује диграм oү. Гласовна група $и \bar{u}$ пише се искључиво у лигатури ч, као што је уобичајено, док се приликом бележења гласовне групе жg, слово д веома често натписује над словом ж. Приликом бележења полугласника углавном се користи танко јер. У ређим случајевима, приметна је и употреба дебелог jера. Слово ђерв у рукопису није ниједном забележено, иако је његова употреба у српској ћирилици посведочена још у XII веку. Стога се друга слова и словне групе употребљавају како би означили глас Ђ (гражданє 54б, такожає 54б, дакономь 45а, агтєль 51а) или $\hbar$ (нощн 56б, керрамндн 59б).

У рукопису је делимично нарушено средњовековно начело спојеног писања речи (scriptura continua). При парцелацији реченице, писар се водио прозодијским карактеристикама, па су реченице подељене на акценатске целине. Стога су енклитике и проклитике увек написане састављено са акцентованом речју (нБратнамь 40а, скнмєєє 42а, нпожьгошєє 43а, вдаморню 43а, ннћ)славланте 44б, наплнншєєе 46б, канамь 49а). Са друге стране, сложенице се у највећем броју примера пишу одвојено (кало шаннє 39б, стєно Бнтннмн

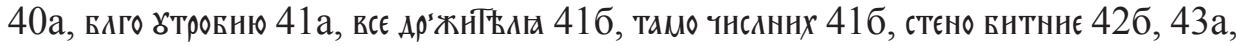
43б, вго мтрн 42б, црн града 43а, 61а, всє ЧЂАр'н 44б, много чнслнн 48а, чАко АюБчє

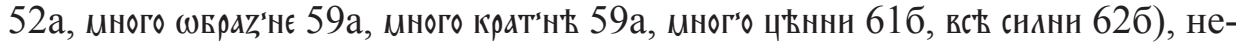
када и са тачком између две речи од којих су настале (тамо - чнсалннє 42а,

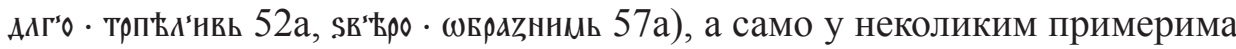
састављено (стеновнтннє 40а, БдговБрнн 42б, БдговЂрннжє 57б, Бдгочастнвниь 62a, вдгочастнвнє 62a). Чест је случај и да се један део сложенице пише састављено са клитиком, док други део сложенице стоји одвојено (састєно внтннмн 41б, нмного мнлостнвь 52а, нчлко люгнвда). Цео текст је написан малим словима, као што је уобичајено за средњовековну традицију. Велико слово 
налази се једино на почетку неке веће смисаоне целине, када је углавном у облику украшеног иницијала. На семантички релевантна места у спису указивано је употребом црвеног мастила - киновара. Тако је на листу 54a црвеним мастилом указано на знамење које има антиципацијску функцију. Од знакова интерпункције писар употребљава углавном тачку на средини реда, али њена функција није да одвоји реченице или смисаоне целине. Веома често она се налази унутар синтагме, између напоредних реченичних чланова, па и између саставних делова сложенице. Стога се уочава да не постоји одређени систем кога се писар држао приликом писања тачке на средини реда. Поред ње, у тексту се налазе и следећи знаци: : $: \sim \sim$, искључиво да означе крај неке веће смисаоне целине. Од надредних знакова у спису су уочљиви акценти, спирити, титла и пајерак. Акценти и спирити писани су на почетку речи или изнад самогласничких слова, веома недоследно. Титла је имала двојаку функцију, да укаже да је реч скраћена и да означи бројну вредност одређеног слова. У складу са средњовековном писарском традицијом, речи су веома често скраћиване како би се уштедео простор. Најчешћи начин скраћивања у овом спису је посредством контракције: н(н)нг 39б,г(Ааго)дптн 39б, г(оспоА)н 40б, в(огородн)цн 41а. Бројна вредност доследно је означавана титлом и тачкама са обе стране слова. Наилазимо и на пример у коме се поред титле, бројна вредност означава и знацима једнакости: $=\not 1=426$. Навика писара да бројну вредност означава титлом резултирала је и неколиким примерима у којима је титла грешком написана изнад речи које означавају бројеве: A $\widetilde{\mathrm{B}} ю 4$ 43б, $\widetilde{A B} \epsilon 436$. Такође, титла је грешком писана и изнад пуног облика оних речи које су у писарској традицији најчешће скраћиване: ко ӝню 42a,

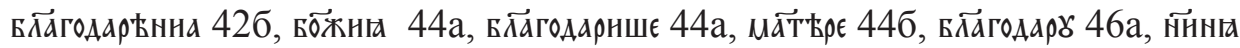
58б. Насупрот томе, забележени су и случајеви изостављања титле изнад скраћене речи, што је евидентно у примеру црьвниь 40а.

Писарски манир овог списа свакако одликује велики број недоследности и неправилности, а употреба пајерка вероватно најбоље указује на оглушивање о дијахронијску перспективу језика. Он се, наиме, готово редовно пише на оним местима у речи где никада није стајао полугласник, а веома често и поред полугласника или пуног вокала. О неправилној дистрибуцији пајерка више ће бити речи у наставку, када се буде говорило о судбини полугласника у овом спису. Такође, необична је појава да се пише лигатура $\ddot{0}$ на оним местима у речи где би требало написати обично

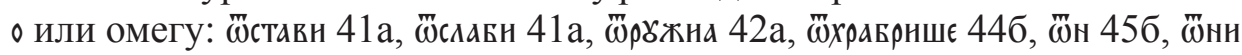

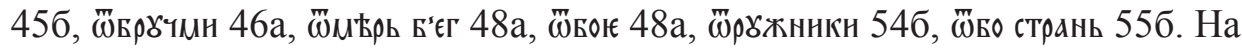
фреквентност те грешке најбоље ће указати податак да је лигатура $\bar{\omega}$ у спису погрешно употребљена чак сто седамдесет и два пута. 
Основни приступ правопису јесте непоштовање било каквог утврђеног система. Гласовна група je, на пример, обележавана је у спису на четири начина: лигатуром є (єсть 60б), словом јат (zлодњњннь 41a, твоњмг 41a,

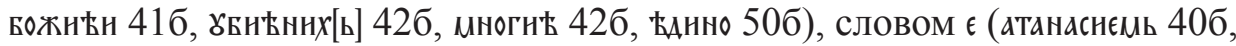
єстАаство 40б, вєлнкне 40б, твоє 41a, дає 42а, єZнкомь 42б) и широким є (малнє 40б, многнє 40б, Блнстаннє 40б, єсн 41a, сазданнє 41a, люднє 47а). Широко є се у средњовековној традицији писало само на почетку речи или слога, када је имало гласовну вредност је. Према томе је и имало ужу употребу него лигатура є, која је могла стајати и после сугласничких слова ( $九$, н, к, г). Међутим, у Спису о паду Цариграда 1453. године, широко є се редовно употребљава иза сугласничких слова, када нема гласовну вредност је:

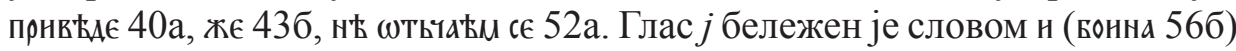
или словом I $(\operatorname{I\epsilon \rho }(\mathrm{s})(\mathrm{A}) \mathrm{A}(\mathrm{H})$ мь 62б). Гласовна група ја означавана је двојако: лигатуром г (покағаннє 41a) и словом а (повЊдюннна $41 \mathrm{a}$, патрнархь $41 \mathrm{a}$, крнчанна

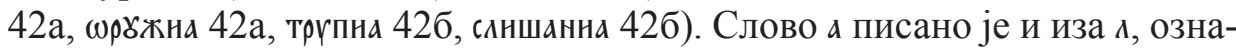
чавајући гласовну групу љљ: нь група jy обележавана је искључиво прејотованим вокалом ю (многою 57б, трою 61а). Гласовна група еје обележавана је словима єє (внвшєє 40а, првєє, $43 \mathrm{a}, х \curlyvee$ жашє 43a), а ни у једном случају словном групом са прејотованим вокалом єєе. Гласовна група аја означавана је двојако, словном групом ах

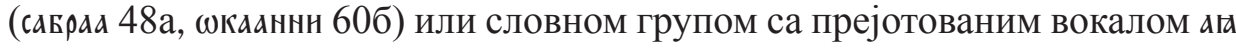
( (тькағанн 40б, чағах 52б). Често постоје различита правописна решења и за реченичне чланове који су у напоредном односу и стоје у неспосредној близини, као у примеру: и на злодњюннњ и въzаконнє (Братнхом сє 41а, где се гласовна група је у наставку за облик именице бележи словом $є$ и словом Ł. Иста појава уочљива је и у примеру: слншавшє рнданнє и смьтєннє 53б, где је гласовна група је обележена словом $є$ и широким $\epsilon$.

Прејотовани вокали писани су и иза гласова који су некада били меки или су могли бити меки (дрєвєною 44а, ндрєщн 44б, Бєжєєџн 49а, прнставнвшє

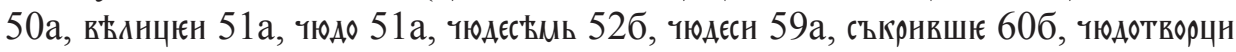
61б, zіємню 60a, zіємлю 61a (2x)), па су процесом депалатализације очврсли. Уочљива је и погрешна употреба прејотованих вокала у примерима: повъдю (3. лице једнине аориста) 426 (3x), 46а, 43a, 50a (2x), прьклюнающє

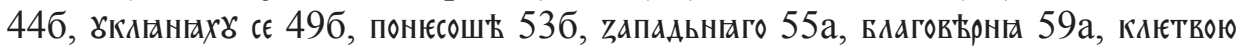

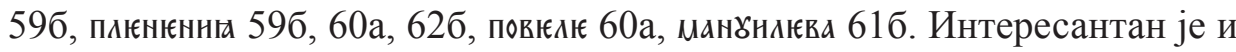
облик плюнениемь $60 \mathrm{a}$, у коме је написано лю уместо $九 \epsilon$, а не уместо ню.

Ни при бележењу вокалног $p$ и $л$ не уочава се доследност. У неким примерима иза њих је писано танко јер: Альгь 45б, зильчав(ь) 45б, мрьтвнхь

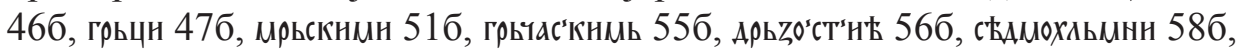


грьтьскоє 62а, вльгарскоє 62а. У одређеном броју примера уместо јера написан је пајерак: мр'твнх[ь] 42б, кр'вь 45а, мрь'твн 48а,гр'кн 48а, крь'вн 61б. Уочљиво је и доста примера који садрже и јер и пајерак: сль'zн 46а, напд'нгахช 46а,

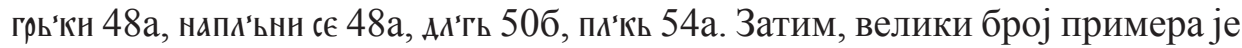
забележен без јера и пајерка: слнц' $40 б$, мртвнє $42 \mathrm{a}$, плнн 42б, нсплннннє 436 , слдамн 44б, наплннш' сє 45a, 46б, наплннтн 46а, гркн 48а, сркскоє 62а, слдамь 62a. Када се уз вокално $p$ и л не пише јер или пајерак, понекад се изнад

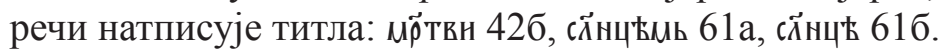

Приликом палеографских истраживања уочава се да су спис писала два писара. Први писар написао је највећи део текста, док је други исписао тек делове листова 54a, 54 и и 60б. Други писар препознатљив је по троугластим облицима слова $\odot$ и а, док главни писар употребљава искључиво обле варијанте тих слова. За разлику од главног писара, који слова н и н пише истоветно, други писар има различита графичка решења за ова два слова. Такође, он лигатуру ч пише извијајући стабло у доњи међупростор, а не усправним потезом као главни писар. Уочава се да други писар бележи јер уз вокално р и и односно натписује титлу уколико их изостави. Та доследност може бити условно схваћена с обзиром на мали број забележених примера (скъzн 54а, трьнґ 54а, дльгь 54а, цр(ь)квє $60 б(2 \mathrm{x})$, прьваго 60б). Приметна је и већа фреквенција дебелог јера него код главног писара (скъzн 54а, вътъzє 54а, съБравь 54б, въ 60б). Значајно је напоменути да се неке устаљене грешке појављују код оба писара, што би могло указивати и на постојање тих грешака у предлошку. И други писар употребљава лигатуру $\widetilde{\omega}$ уместо обичног слова $\bullet$ или омеге. Такође, оба писара бележе јат где му није по етимологији место у речи. Јат се веома често пише уместо прасловенског $e$ или уместо $e$ које је настало деназализацијом прасловенског вокала А. Јат се бележи и у речима позајмљеним из страних језика, али се са друге стране у прасловенским речима које су имале вокал јат, веома често бележи вокал $e$. Недоследност у поштовању правила или њихово непознавање, па самим тим и немогућност примене на фонетски, морфолошки и синтаксички систем језика, одликују свакако оба писара.

Поред вокала савременог српског језика, у Спису о паду Цариграда забележени су и вокали: †, ь, ъ, ы, као и вокално л. У њиховој употреби углавном има доста недоследности. Најдоследније је бележено вокално $л$, које није ни у једном примеру у тексту замењено вокалом $y$ : плнн 42б, нсплнгнне 43б, слұамн 44б, наплннш' сє 45a, 46б, АльГь 45б, умльтав(ь) 45б, напл'ннаху 46а, пл'кь 54а, съамохльмнн 58б, сл(ь)нць 61б, 62а, слұам[ь] 62а, вдьгарскоє 62а. Оваква употреба нарочито зачуђује због чињенице да је 
вокално $л$ између XIII и XV века нестало са највећег дела српске језичке територије. Доследна и правилна дистрибуција вокалног л може писара довести у везу са призренско-тимочким дијалектом, у коме се оно и до данас сачувало. Вокал јери забележен је само у неколиким примерима: многнмы 43б, вл'ьм'Ужємьн 45б, нощьн 48а, гр'кьї 56а, свєтьє 58б, свєтьїн 61б, свєтьїє 61б. Много је више примера небележења овог вокала тамо где му је

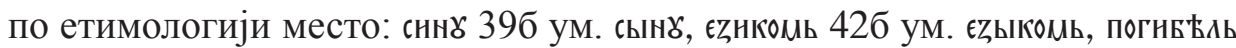
$49 б$ ум. погыБЊ $л$, рнданнє $53 б$ ум. рыданнє, тнсбщє 586 ум. тысðщє. Ова појава није изненађујућа, с обзиром на то да се вокал јери изједначио са вокалом још у Х и ХІ веку.

Проучавање дистрибуције слова јат у овом спису резултирало је одређеним запажањима која би ваљало напоменути. У великом броју примера јат је написан тамо где му је по етимологији место: повъ'ть 39б,

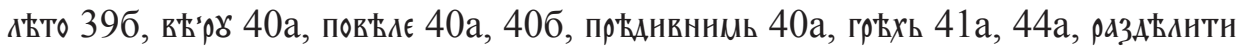

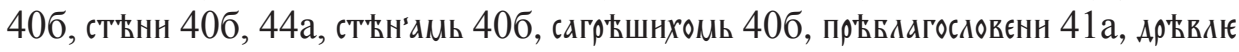

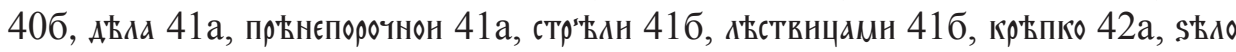

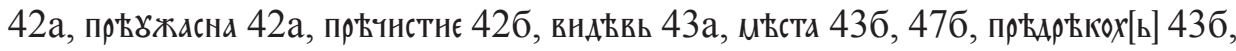

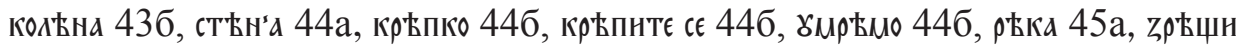
45a, 48a, uћсто 47б, sвЂрнє 48а, врЂмє 48б. У одређеним речима приметна је екавска замена јата: sвєъдн 40б, месте 44a, мест૪ 44a, стєна 44a, место 44a, 47б. Изненађујуће је што истовремено неке речи имају ијекавску замену јата, што потенцијално може указивати на то да писар потиче са неког граничног подручја: гнєвь 59а, 62а, гнєва 44a, 47a, лєствнцн 55а. У великом броју примера јат се бележи уместо $е$ : въльм४жн 40а, Аћкємрнга 40а,

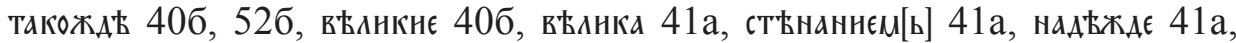

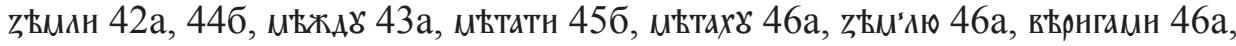

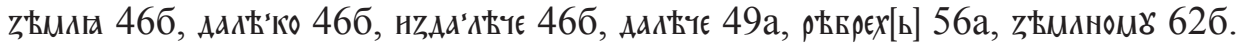
Јат се бележи и уместо $e$ које води порекло од назалног вокала А: кльтавь

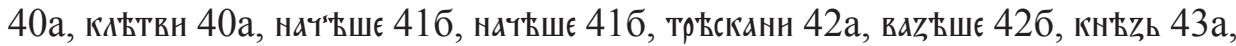

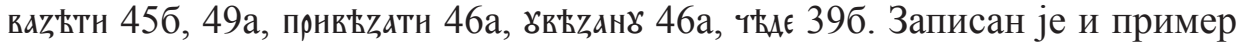
дҺвьтн да означи број који је у старословенском имао облик дєвАтн. Јат се неправилно бележи у префиксима (въzвожнмь 42б, в вzпочнванна 43а, 43б), инфиксима (кошъвє 46а, кошњвь 46б), суфиксима (вдагодарьнна 42б), у речци не (нЊ прєадждь 41a, нЊ (ставн 41a), рефлексивној речци се (разснпа съ 47б, ндвавн сь 50a), речци же (царь жь 57a). Уочљиви су и примери где у истој речи постоји и правилна и неправилна дистрибуција јата (въzпрьстанно

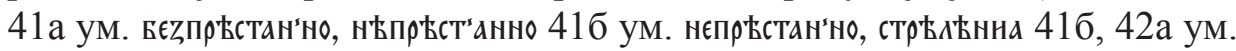

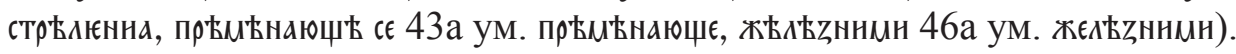
Неправилна дистрибуција јата приметна је и у деклинацији и конјугацији 
променљивих речи. У наредним примерима јат је неправилно написан као наставак за облик акузатива множине: постав'нш' пбшкн н кош' н иҺствнц' 55a, н прндвда волгарь н воњв'одь 59б. Још је фреквентнија погрешна употреба јата у наставцима за грађење одређених глаголских облика. У трећем лицу множине аориста, јат се употребљава уместо $e$, које води порекло од прасловенског назала А (прнставншъ 41б, нападошњ 41б, 53а, скаzашъ 42б, ваZлюБншњ 43б, Уготоввншъ 47б, оүАарншњ 47б, развалншњ 47б, васкочншњ 47б,

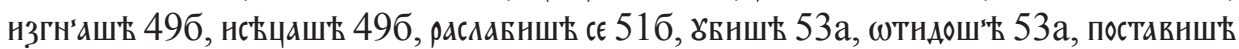
54б, рькошь 54б, почр'ьвьне'шњ 61б). У трећем лицу једнине аориста јат се употребљава уместо $e$ (пондњ 42б, постндњ сє 46а, нападь 48a, 53a, нұндњ 53a, дадt 59б). Слово ь погрешно се пише уместо е и у трећем лицу једнине имперфекта (помншлғшь 42б). У овом спису забележен је и велики број примера погрешне употребе јата у партиципу презента актива: клнч४щњ

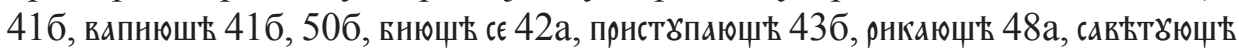

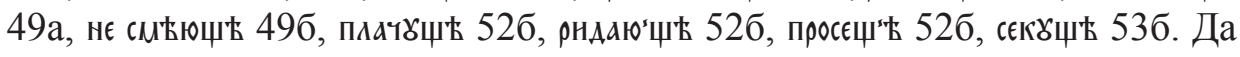
постоји изузетна недоследност у бележењу наставака за аорист и партицип презента актива уочљиво је и у следећем примеру: васкрнчашє н напа'дош' н

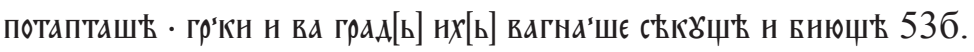

У Повести о паду Цариграда бележе се и дебело и танко јер, при чему је посведочена учесталија употреба танког јер. То је сасвим у складу са српском традицијом, по којој се полугласник често писао тамо где је у говору изгубљен још у X веку, након престанка деловања закона отвореног слога. Танко јер било је погодније за употребу првенствено зато што је заузимало мање простора на пергаменту. У следећим примерима забележено је танко јер на месту где је некада био полугласник у слабом положају: въдьмљжн 40а, ароматьскнми 51а, въzьчнслноє 52а, ндьгнашь $56 б$. Полугласник у слабом положају који се налазио на крају речи готово редовно је бележен: многнмь 40а, саворь 46б, єднномь 47б, логофеть 49а, с8џниь $50 \mathrm{a}$ У неколиким случајевима забележен је и полугласник поред вокала, где је његово бележење свакако било сувишно: нұьєжь 40б, знновнаньннь 43а, ваzврачьаху 49б, нұьшвндн 59а. Забележено је и мноштво примера са невокализованим полугласником: (гьнь 46а, нєдогьрь 47а, мьчь 49б, съвьтннкн

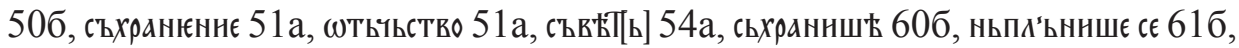
сьставлюннє 61б. Међутим, записан је и велики број речи у којима је извршена вокализација: ваздвндає 39б, сатворьнннхь 39б, васн 40а, вазмогошє 40а, васа 41a, васе 41а, васклнкнгше 41б, васклнчашє 41б, вась 41б, множаство 42а, м४Жаставно 43б, сатворнтн 44а, 47а, васканча 44а, васакнин 44б, ваз Бтнє 44б, ваз Бтн 49а, вазоромь 53а, вазрастомь 53а, сатворншє 61б. Уочава се да вокализација полугласника није доследно спроведена у спису. Уместо дебелог или 
танког јер, на месту некадашњег полугласника могао се писати и пајерак,

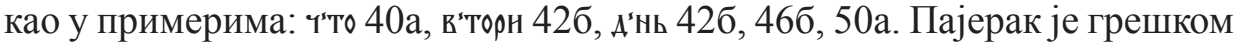

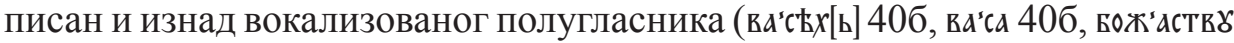
41a), као и изнад оног а које није настало вокализацијом полугласника (вра'гн 41б). Забележени су и примери у којима се на месту некадашњег полугласника није писао ни пајерак ни јер ни вокал а: всн 40б, всє 41a, 48б, второе 44а, днн 46а, 47б, 47a, 48б, всь 46б, днємь 47б, крћпкъь 48а, м૪дрь 56б, нскуснь 56б, всью 57 а.

Симптоматична је употреба пајерка на оним местима на којима се полугласник свакако није могао налазити. Таквих је случајева у овом спису

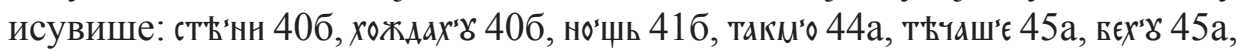

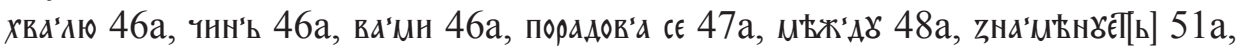

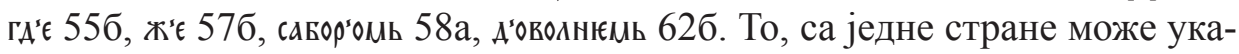
зивати на писарево недовољно познавање етимологије речи и фонетских принципа језика, а са друге може указивати на недовољну свест о томе шта пајерак треба у тексту да представља.

Проучавање консонантског система такође је резултирало значајним запажањима. Африката sело, која има прасловенско порекло, поред уобичајене бројне, има и гласовну вредност: sвєzдн 40б, sъло 42a, 43a, 48a, sъла 43б, sвъ'рнє 48а, sвњрн 62а, sвъzдн 62а. У одређеним примерима ово слово замењено је словом з (злодьюннь 41a, кнъzь 43а, здотастнвнхь 62б) што указује на тадашње стање у језику, за разлику од претходних примера, где су поштовани етимолошки принципи при бележењу облика речи. У спису је уочљива и употреба грчких слова, наслеђених из старословенске писме-

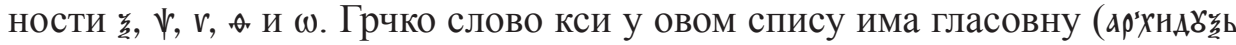

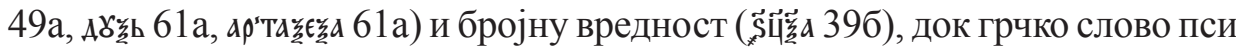
у спису има само бројну вредност (д̈үй 42б, $\vec{\xi} \uparrow 45 \mathrm{a})$. Слово тита користи се при бележењу грчких имена: өєюдор 48б, ө.0м 61а. Две надредне тачке изнад ижице по правилу имају дијакритичку функцију, додају се када слово има гласовну вредност $u$, док без тачака има вредност сугласника 8 . Ижица у овом спису у свим примерима има гласовну вредност $u$, и углавном се бележи двема надредним тачкама (кӥрь 49а, магїстратом[ь] 54б, магйстратн

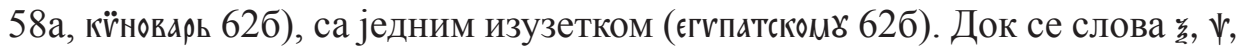
$\checkmark$ и $\bullet$ употребљавају у позајмљеницама из грчког језика, $\omega$ се користи да

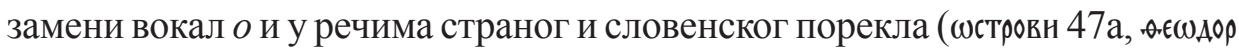
$486, \omega 486$, (вхождаху 51б). Фрикатив $\phi$ користи се искључиво у речима страног порекла: фрбгн 46а, фравУра воє'вода 48а, логофєть 49а. Иницијално в је доследно сачувано (васклнча 44а, вазьтнє 44б, вадттн 49а, вдzоромь 53а, вазрастомь 53а, васк'орь 53a), за разлику од народног говора, у коме прелази у 
вокал ү. Консонант $\mu$ бележи се у речима турског порекла: санџакь Бєгн 50а, Бахтаџн пашу 57б, санџак вєга 59б, 60а. Задњонепчани сугласник $x$ изостављен је у примеру равро 43б, под утицајем народног говора, али су забележени примери: хр'аврость 49a, храврость 54а, хравростн 57a. Исти глас изостављен је и у примеру пома'авь рукою 60а, при чему је дошло до стварања хијата. Са друге стране, слово $x$ је натписивано изнад речи на оним местима где му по етимологији није место (на бтрнах жє 42б, распра вєх въднг 43а). На оваква колебања у дистрибуцији слова $x$ свакако је имао утицај народни говор, у коме се глас х почео губити крајем XVI века.

Поред словенских речи, у спису је евидентан одређен корпус речи

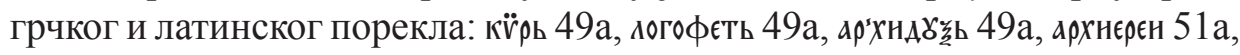

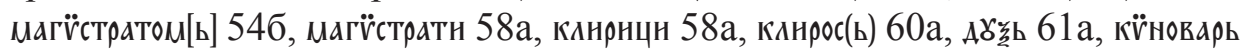
62б. Такође је приметан одређен број речи које су преузете из турског је-

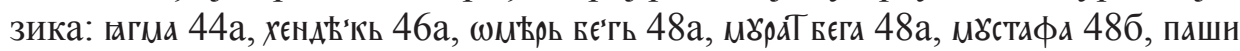

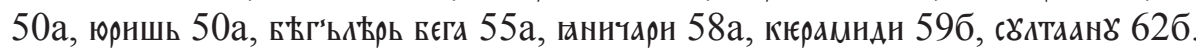

Постоје бројне недоследности и у бележењу гласовних промена у речима. У следећим примерима извршена је палатализација: грцн 40а, 46б, фрүзн 40а, вълнць 40а, тъшццє 40а, стрєлннццн 40б, турцн 40б, 41б, 43а, 43б, 45а, 46б, 47б (2x), 48а (2x), дрбън 41б, потоцн 42б, фрбън 43а, вълнцц 43б, вълнццн

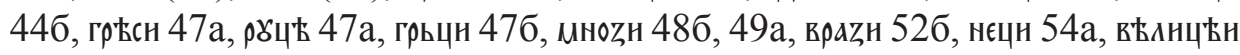
55б. Међутим, постоји велики број примера у којима палатализација није извршена: посланнкн 40a (2x), дькємрнга 40а, грьшннккн 41а, врагн 41б, пбшкн 41б, 48б, туркн 43б, 46а, 46б, 48а (2х) стратнгн 44б, фругн 46а, грњхн 47б, гр'кн 48a, грь'кн 48a, гркн 48а, свњтнлннкн 51а, шрбжннкн 54б. Међутим, постоји велики број примера у којима палатализација није извршена: посланнкн

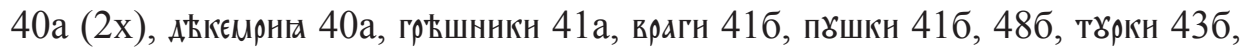
46a, 46б, 48a (2х) стратнгн 44б, фругн 46а, грђхн 47б, гр'кн 48а, грь'кн 48а, гркн 48a, свьтнлннкн 51a, шрбжннкн 54б. Веома често звучни сугласници стоје поред безвучних, чиме се одступа од бележења оних гласовних процеса који су у говору извршени: подкопаватТн 46а, раzсєА⿱ сє 46a, разснпа сь 476 ,

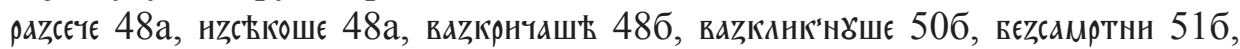

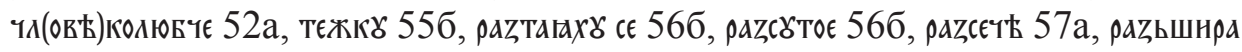
сє 61б, разккопан[ь] 62a, срвскоє 62а. У одређеном броју примера извршено је једначење сугласника по звучности, односно речи су забележене онако како су се изговарале: раславншє 47б, нсъцашь 49б, раслагнш' сє 51б, нсњкошњ с 58б. Једначење сугласника по звучности некада се врши и унутар једне фонетске речи: ис црькве 60б, док у другим примерима то није случај: нz црьквњ 60 , нъ црквє 60б. Некада се записује полугласник из префикса, па је немогуће да се гласовна промена изврши вазьстьнғашє 47a, разьс''́кашє 496. 
Ови примери свакако не илуструју стање у говору, јер се полугласник у префиксу не изговара од када је престао да важи закон отвореног слога. Један до другог се пишу и они сугласници који се не могу изговорити заједно (кєзZаконна 47а, вєзZаконнн 62а, вєZZаконоє 62а), али забележени су и примери са губљењем једног сугласника (єєзаконовахомь 40б, въzаконнє 41a). Сугласничка група нн у придевима и прилозима остаје неупрошћена и најчешће се пише без пајерка (въzпрьстанно 41б, ньпрьстанно 41б, 43б, 44б,

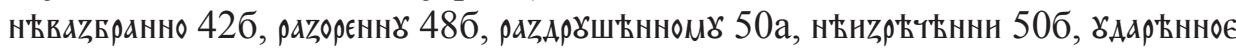
$53 \mathrm{a}$, нұБранннин 53б, камьнно 56б, погрьБєннУю 62б), а тек у ретким примерима са пајерком ( доследно се удвајају самогласници (кнвшєє 40a, ратнад 40б, многад 41a, хуждшєє 43a, потрєьнда 49а, снлнад 55a), али се понекад по аналогији грешком удвајају и самогласници у именицама које стоје до њих (съш'ал гх‘авда 60б, многа ннад zлад 62а). Самогласници се веома често неправилно удвајају:

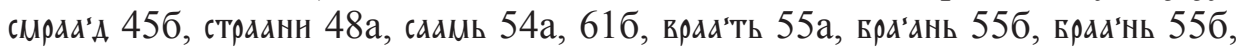
враднь 57а, враатомь 58б, в’рат’ад 60а, врадть 60а, злаатннх[ь] 60б, Бладга 61б, храдмн 62а, съитаднг 62б. Релевантна је појава и гласовне групе чр (чрьнљ 54a, почр'ьвьне'шЊ 61б) с обзиром на то да указује на чување архаичнијих слојева језика. Ч се испред $р$ изменило у $и$ на целој штокавској територији, што је посведочено још у првој четвртини XIII века.

Из свега наведеног може се закључити да је недоследност најистакнутија особина овог преписа Повести о паду Цариграда. Недоследност је присутна у многим аспектима текста: фонетском, морфолошком, синтаксичком, ортографијском и палеографском. Најчешће прављене грешке указују на оскудно образовање преписивача и његово непознавање историјског развоја језика. Такође, с обзиром на то да се находе код оба писара, треба у обзир узети и могућност њиховог постојања у предлошку.

У прилогу рада прилаже се приређени текст Повести о паду Цариграда 1453. године према препису из треће четвртине XVII века, из рукописа Патријаршијске библиотеке број 343.

\section{ЛИТЕРАТУРА}

Барбаро 1856: N. Barbaro, P. V. Corredato di note e documenti per Enrico Cornet, Giornale dell' assedio di Constantinopoli 1453, Vienna.

Ђорђић 1990: П. Ђорђић, Историја српске ћирилище, Београд: Завод за уџбенике и наставна средства.

Јорга 1927: N. Jorga, Une source négligée de la prise de Constantinople, Bulletin de la Section Historique, Academic Roumaine, Bucarest. 
Кримски 1924: А. Кримськии, Історія Туреччини I, Зборник історично-філологічного відділу Української академії наук, 10, Київ, 69.

Леонид 1886: А. Леонидъ, Повъсть о Царьградъ (его основаній и взятій Турками въ 1453 году) Нестора-Искандера XV въка (по рукописи Троице-Сергіевой Лавры нач. XVI въка, $\mathrm{n}^{\circ}$ 773), Памятники древней письменности и искусства, 63.

Мијатовић 1892: C. Mijatovic, Constantine or the conquest of Constantinople by the Turks, London: S. Low, Marston \& company limited.

Милер 1870: K. Muller, Fragmenta historicorum graecorum, Paris: Editore Ambrosio Firmin Didot.

Пипин 1857: А. Н. Пыпин, Очерк литературной истории старинных повестей и сказок русских, Санкт Петербург: Имп. Акад. науке.

Трифуновић 1990: Ђ. Трифуновић, Азбучник српских средновековних къижевних појмова, Београд: Нолит.

Унбегаум 1929: В. Unbegaum, Les relations vieux-russes de la prise de Constantinople, Revue des études slaves, 9, Paris, 1-2.

\section{Ksenija V. Milovanović \\ THE RECORD ON THE FALL OF THE CONSTANTINOPOLE 1453. ACCORDING TO A XVII CENTURY MANUSCRIPT}

\section{Summary}

The record that thematicizes the conquering of Constantinopoleoriginally comes from the late XV or early XVI century Russian literature.It was composed by Nestor Iskander and it is entitled The tale on the Taking of Tsargrad 1453. The manuscriptof the record written in Serbo-Slavic that dates back to the last quarter of the XVII century is kept at The Belgrade Patriarchate Court library. The work examines phonemic,morphological, lexical andpalaeographical characteristics of the language. The purpose wasn't to present the described occurrences on the synchronic level, the diachronic perspective is rather dominant. The exemplified entries are linked to Proto-Slavic and Old Church Slavonic forms. It particularly focuses on the vocalization of the semivowels, that wasn't properly carried out, as well as on the irregular distribution of the letter Yat. The supplement features the adapted text of the The record on the fall of the Constantinopole 1453.

Key words: The record on the fall of the Constantinopole, Nestor Iskander, the history of the language, paleography, vocalization ofthe semivowels. 


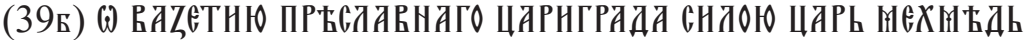

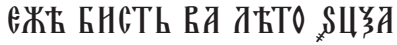

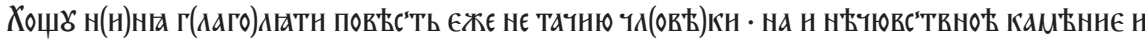

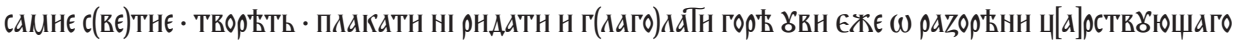

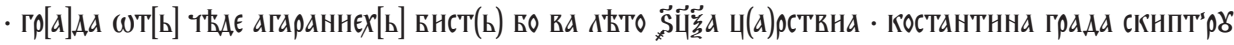

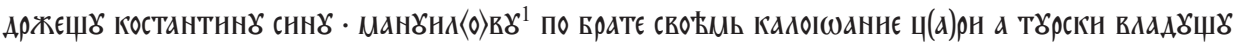

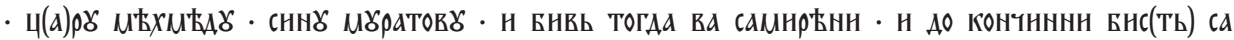

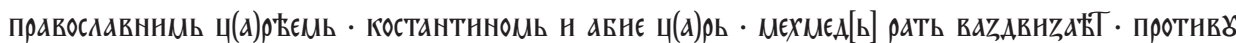

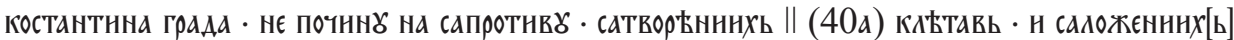

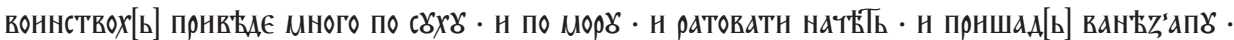

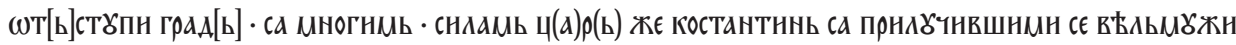

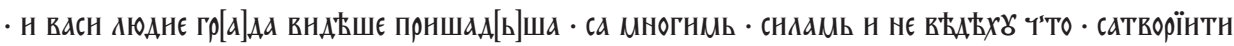

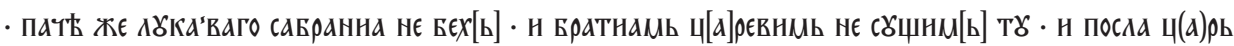

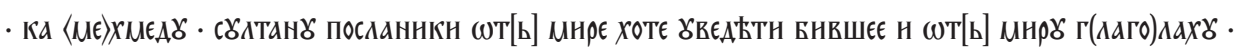
(

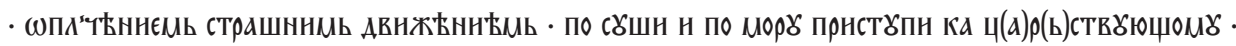
Град

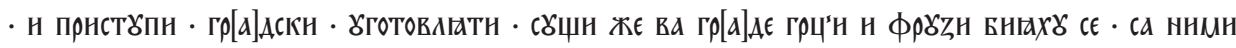

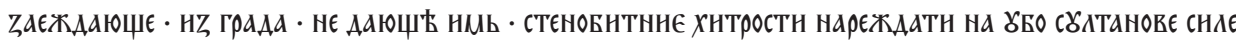

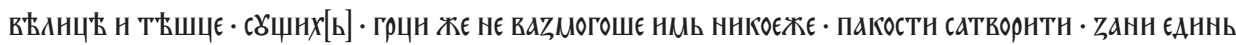

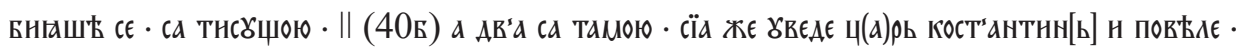

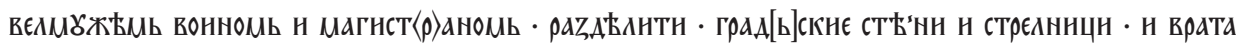

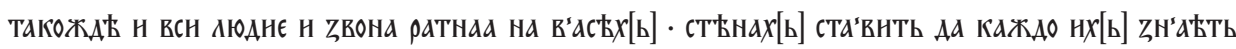

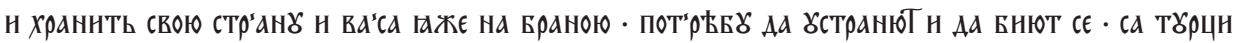

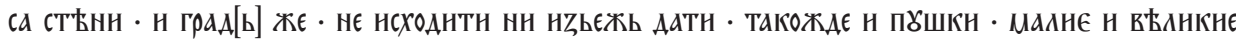

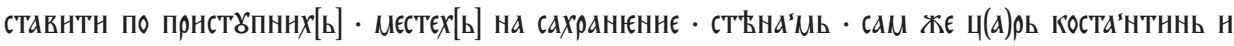

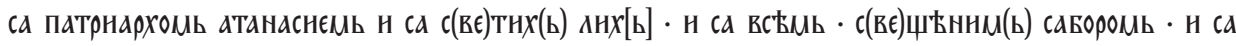

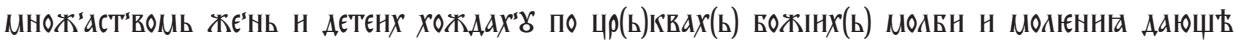

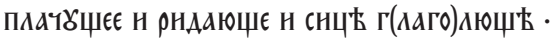

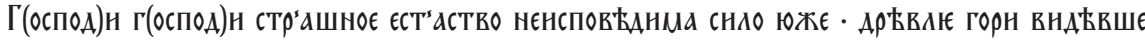

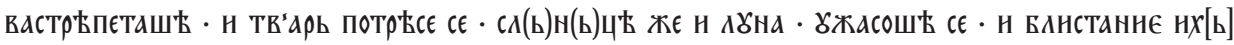

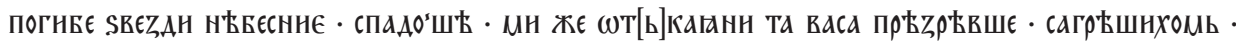

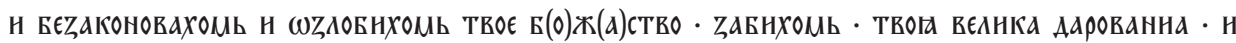

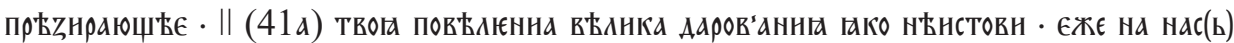

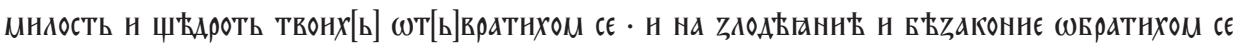

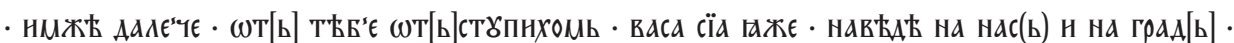

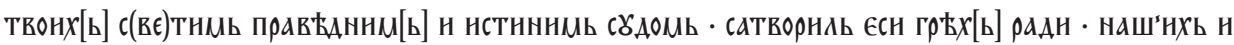

\footnotetext{
${ }^{1}$ Написано мднбнднвъ.
} 


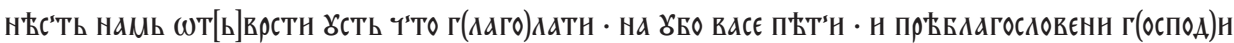

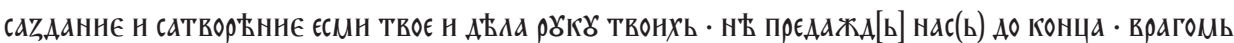

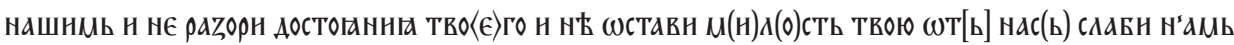

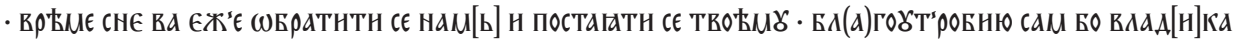

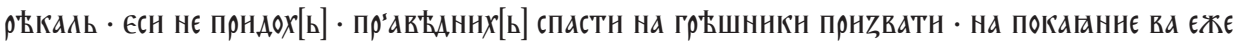

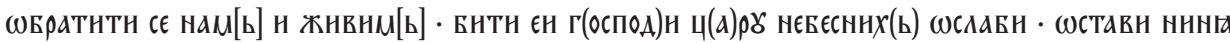

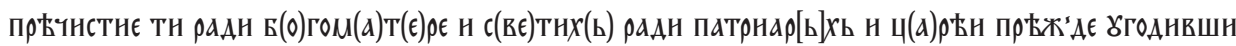

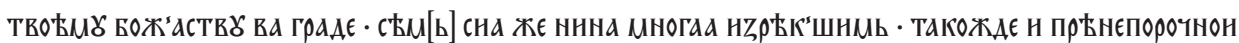

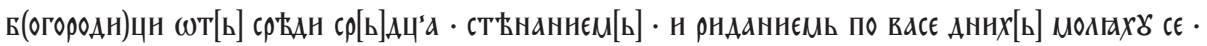

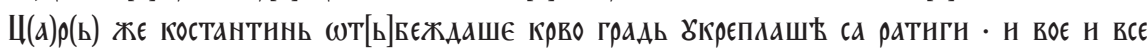
АюАН Аа Н'

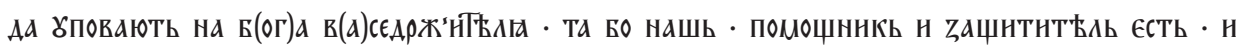

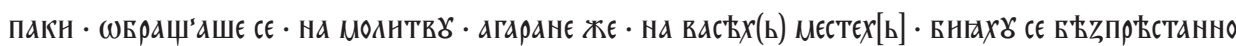

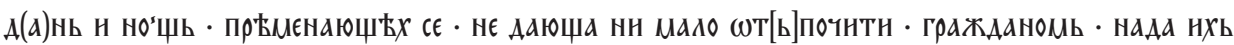

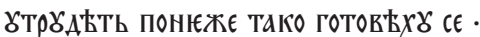

Ка прнстУПЪ · н ТаКо творахУ

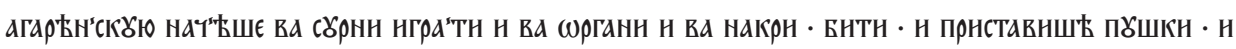

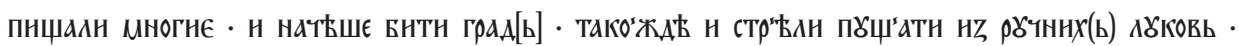

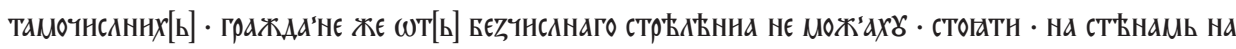

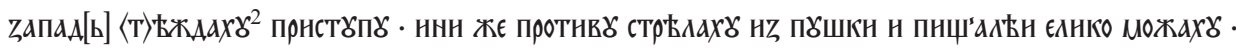

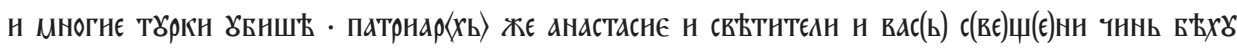

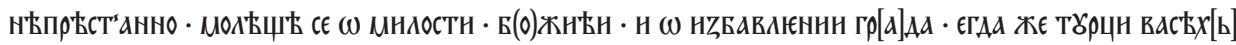

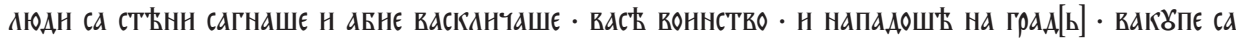

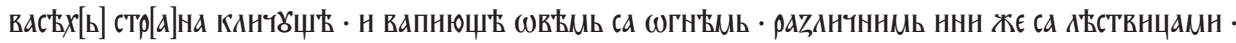

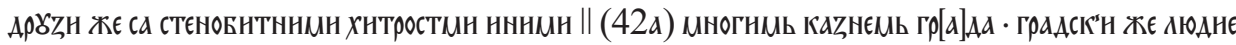

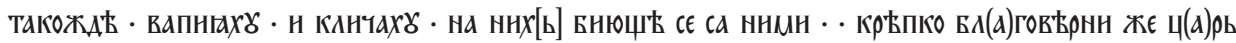
КоСТанТНнь

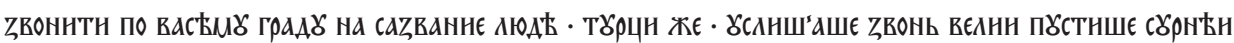

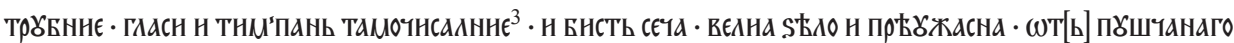

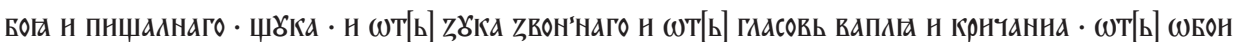
АюдБН · Н

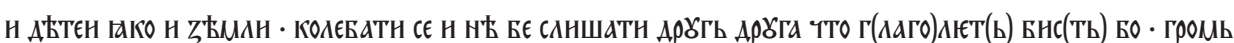

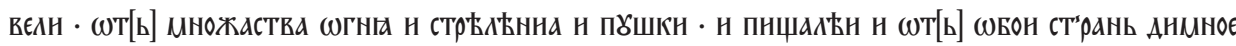

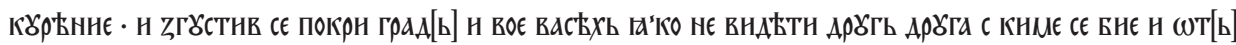

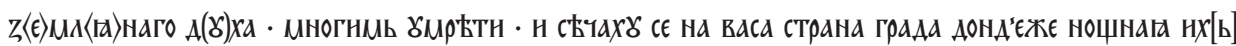

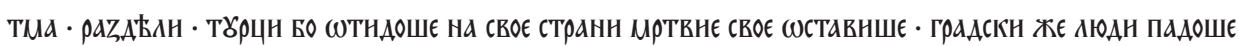

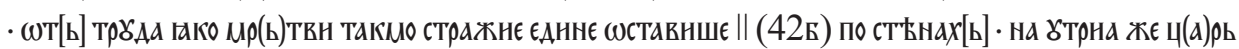

\footnotetext{
${ }^{2}$ Написано шьждаху.

${ }^{3}$ Написано тамо - чнсалнне.
} 


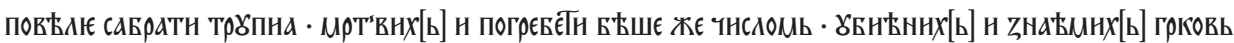

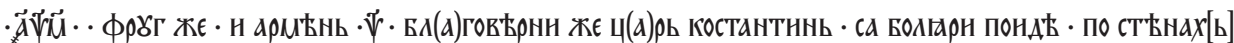

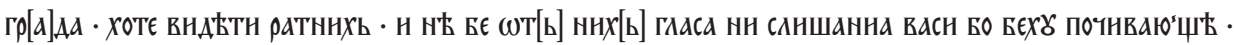

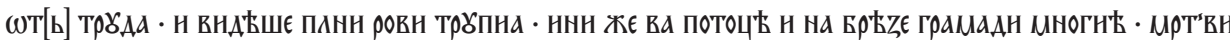

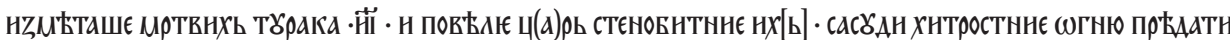

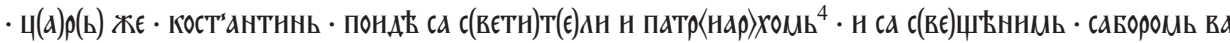

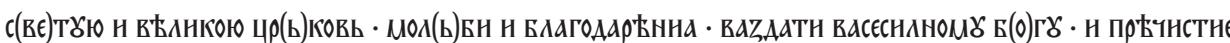

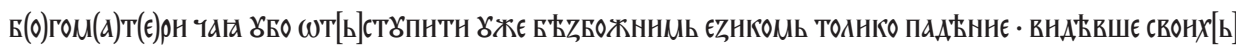
ратннХ[Б]

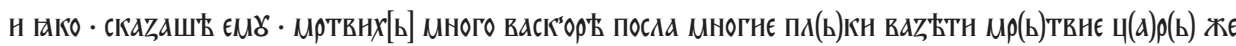

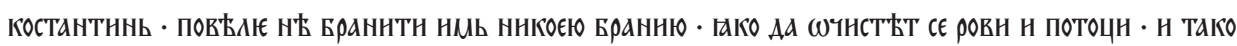

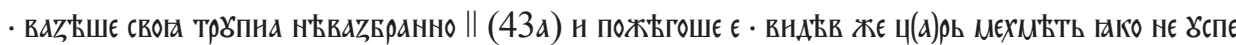

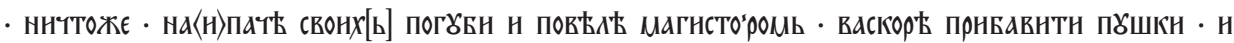

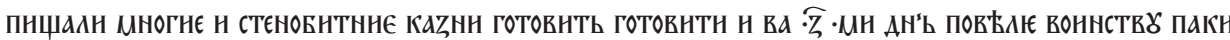

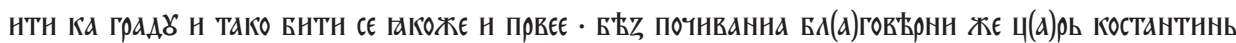

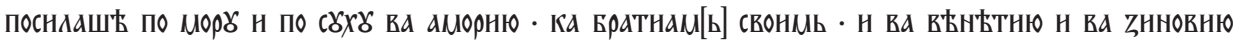

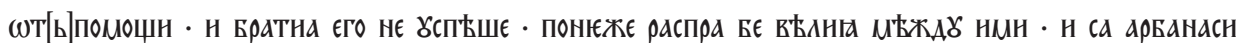

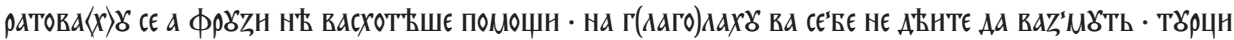

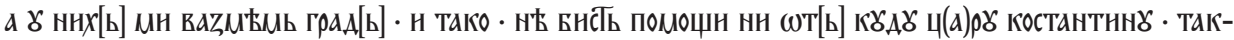

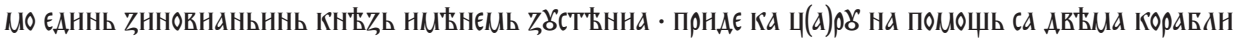

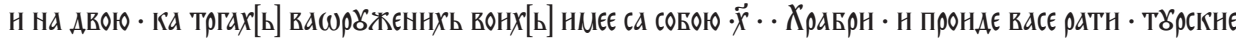

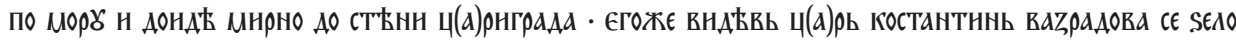

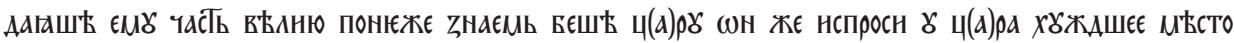

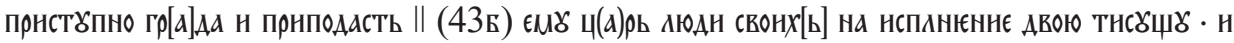

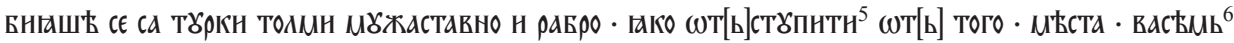

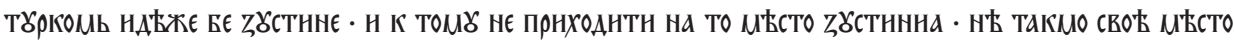

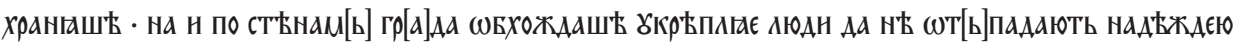

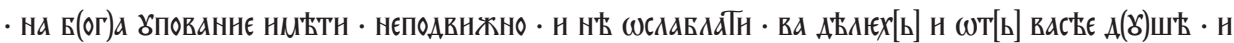

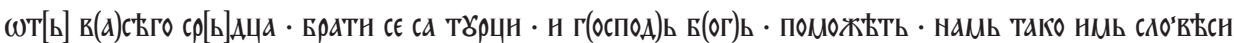

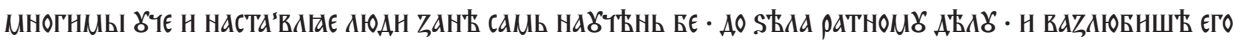

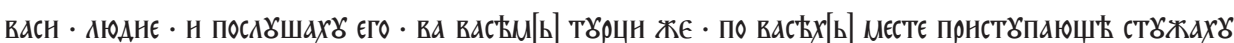

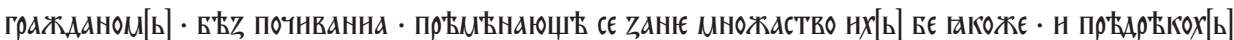

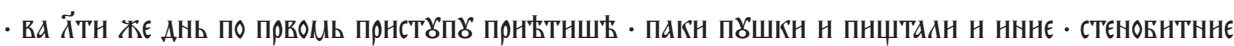

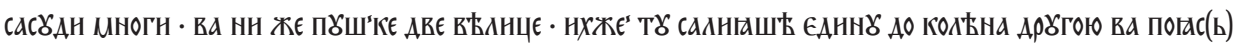

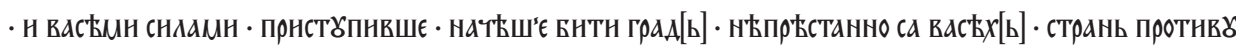

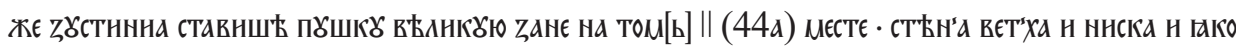

\footnotetext{
${ }^{4}$ Написано патрхаромь.

${ }^{5}$ Написано

${ }^{6}$ Написано васъмь васъмь.
} 


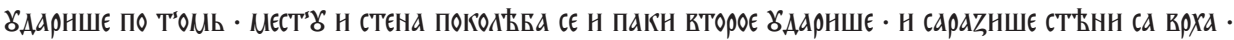

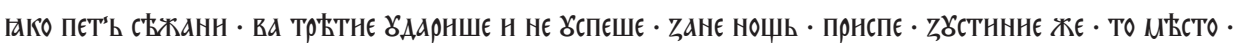

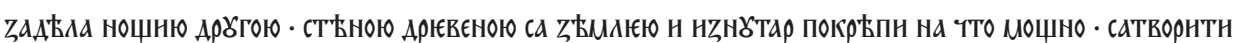

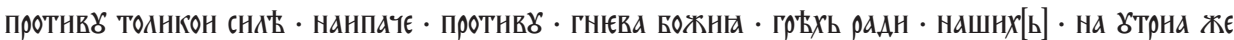

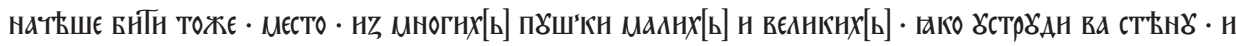

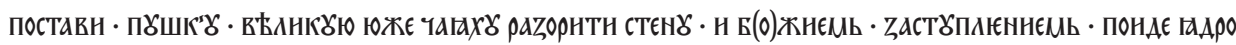

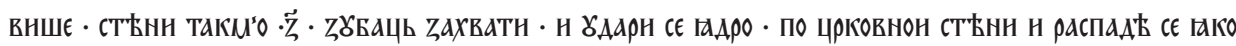

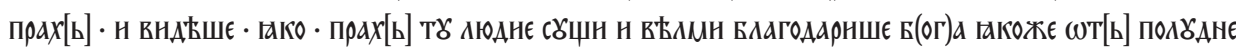

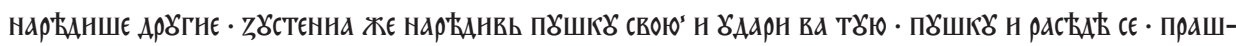

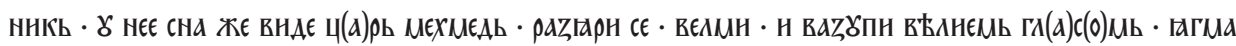

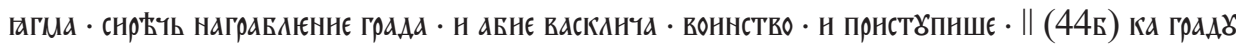

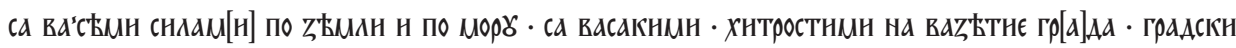

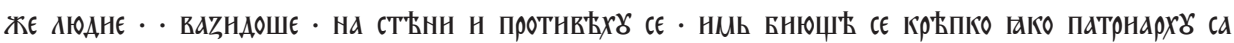

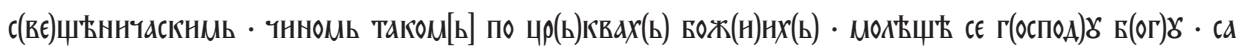

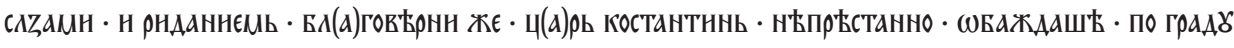

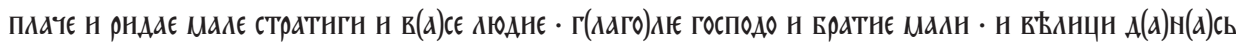

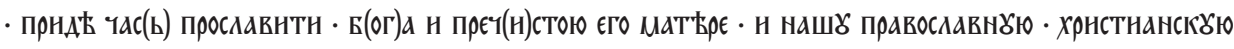

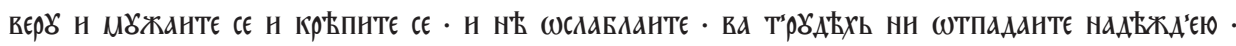

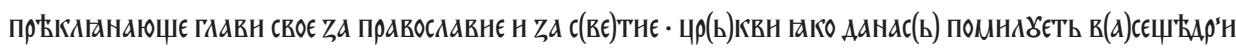

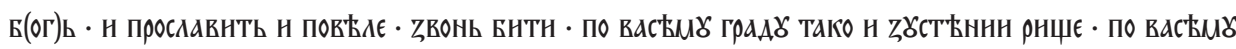

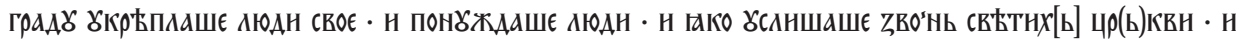
аБНє ӘКрФПНШЕ СЕ Н

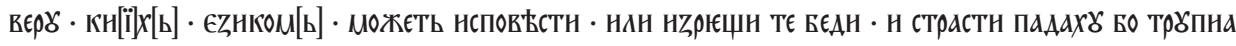

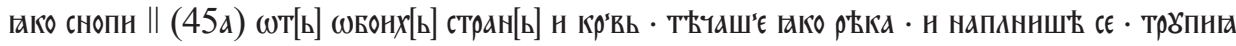

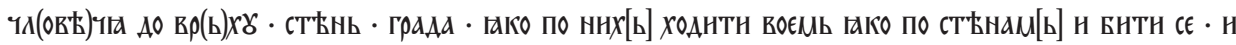

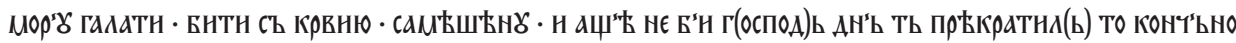

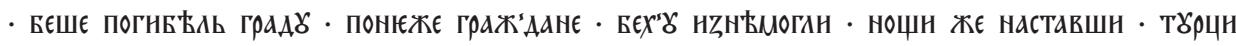

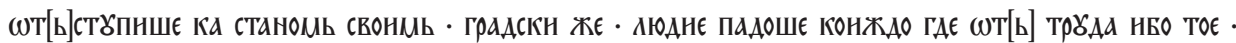

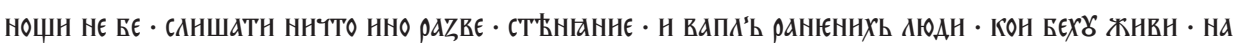

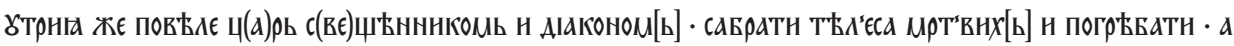

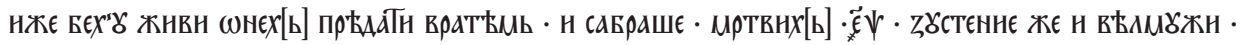

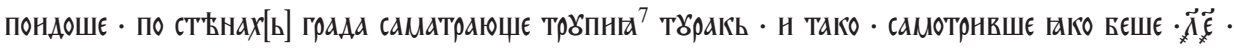

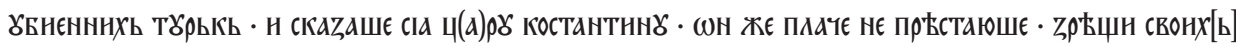

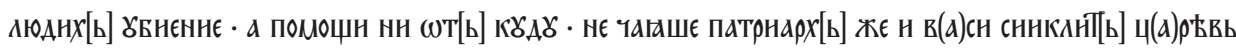

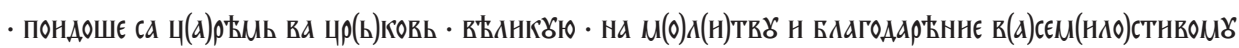

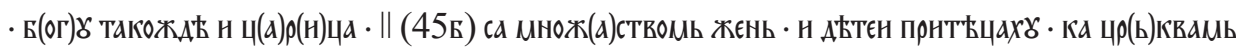

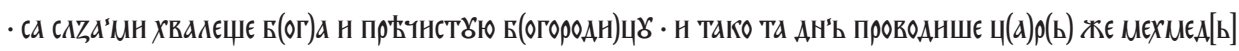

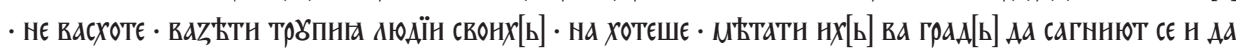

\footnotetext{
${ }^{7}$ Написано трбпнга турбпннга.
} 


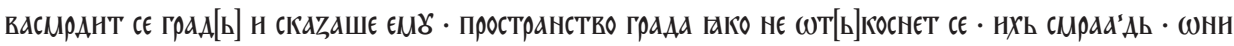

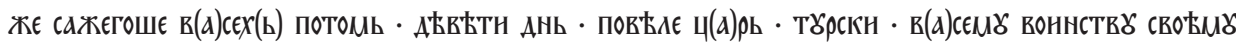

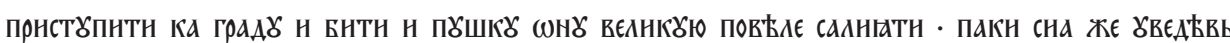

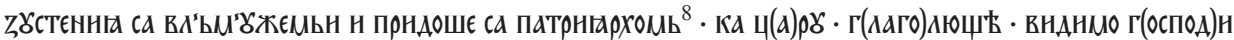

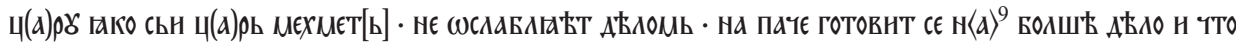

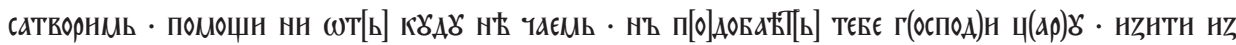

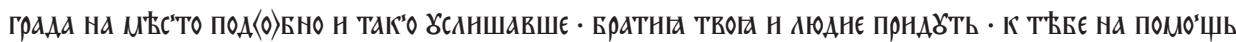

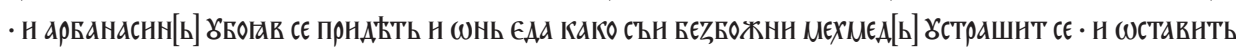

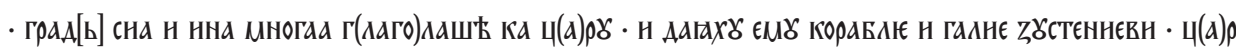

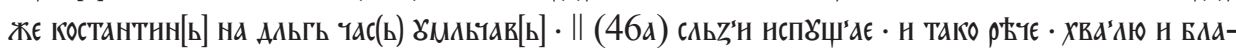

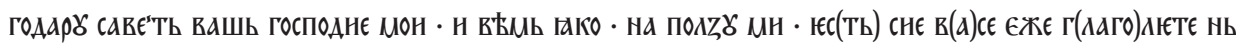

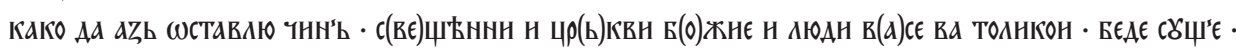

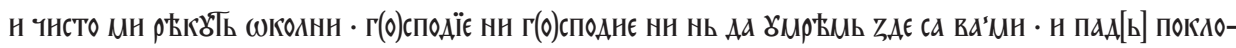

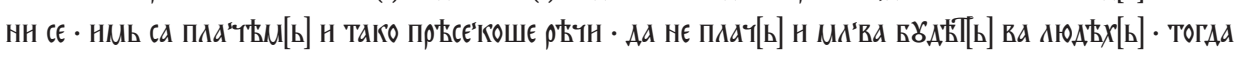

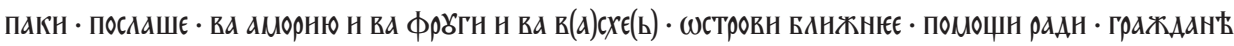

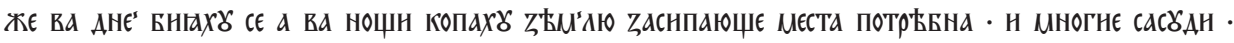

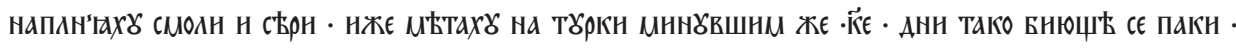

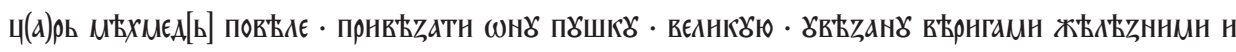

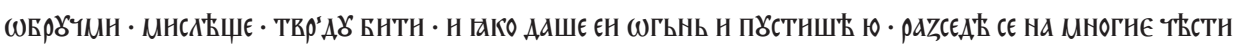

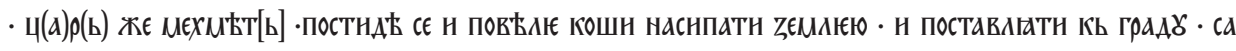

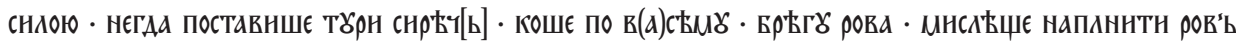

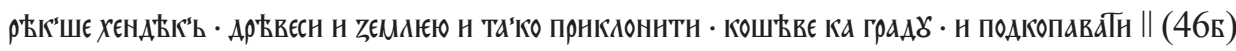

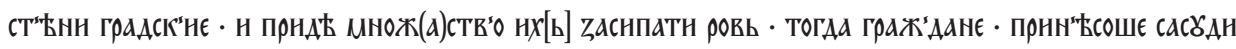

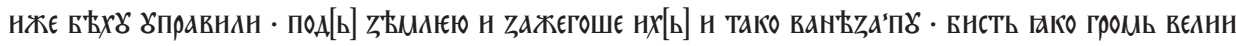

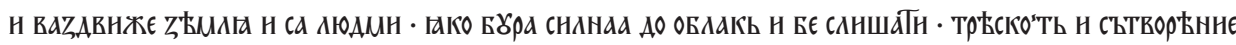

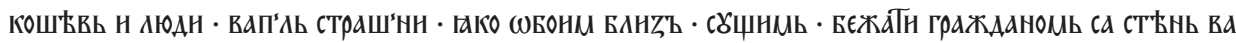

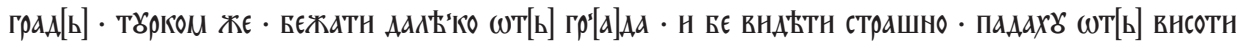

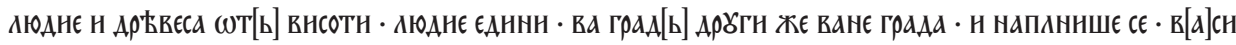

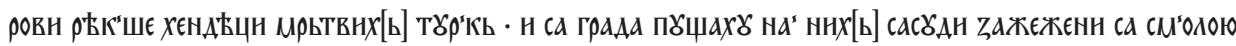

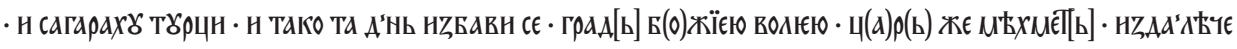

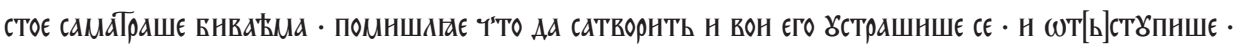

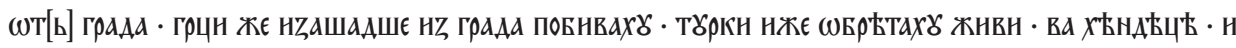

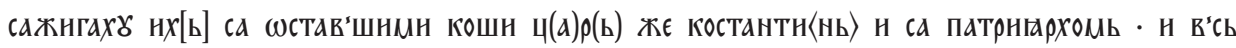

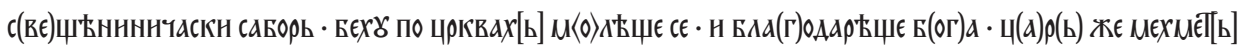

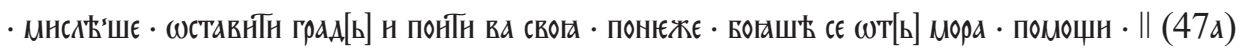

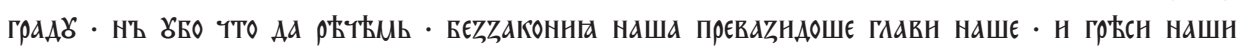

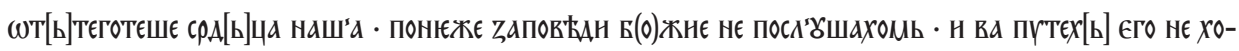

\footnotetext{
${ }^{8}$ Написано пратрнгархомь.

${ }^{9}$ Написано нь.
} 


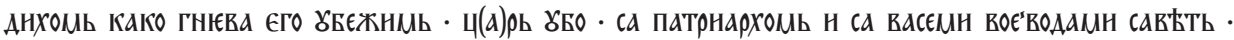

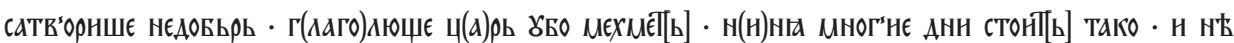

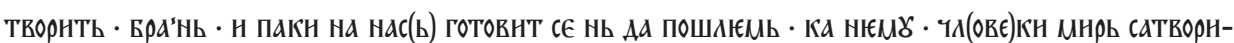

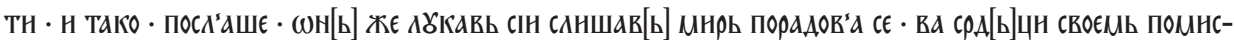

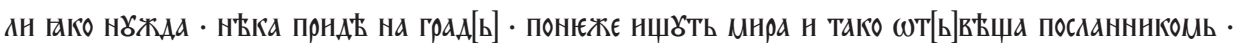

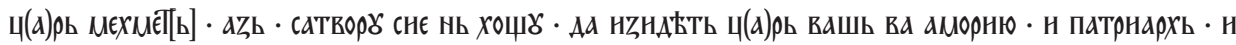

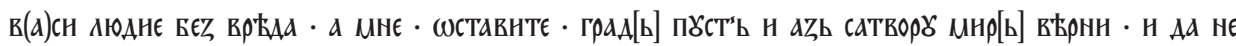

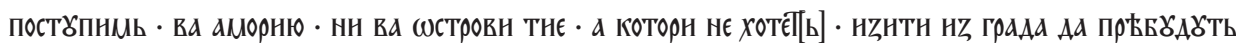

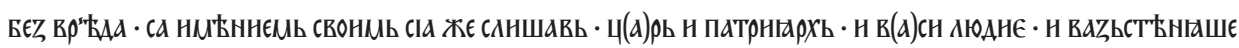

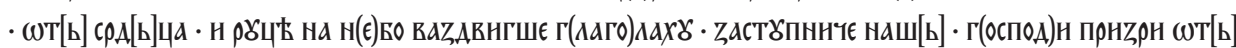

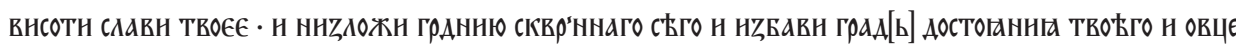

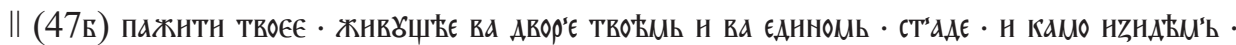

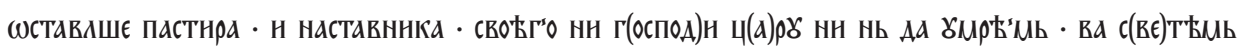

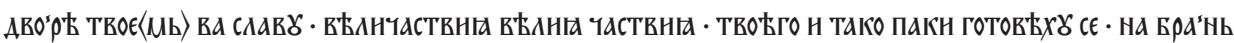

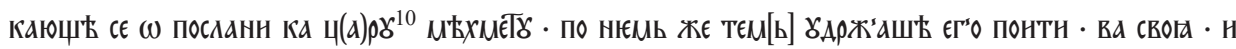

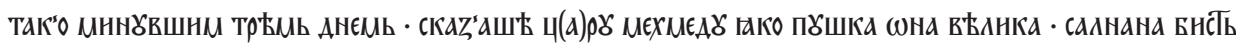

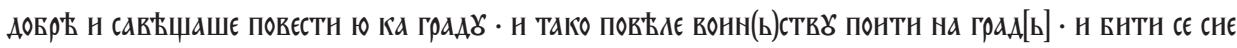

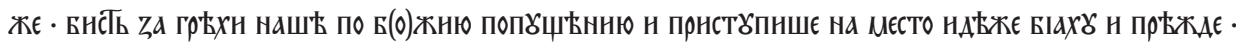

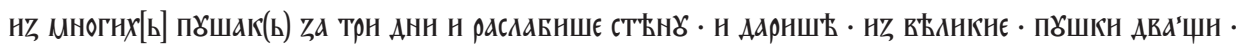

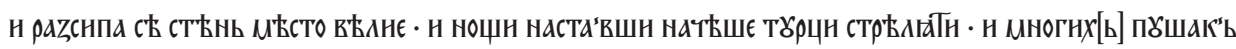

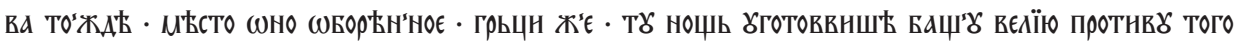

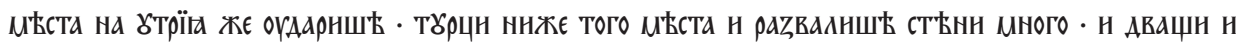

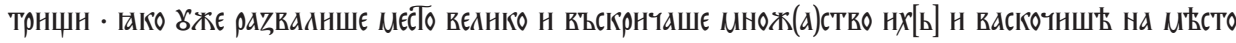

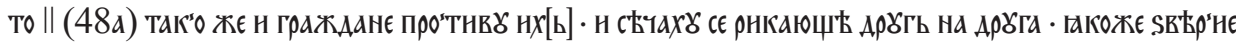
АНвн н Бє СТрашно ZрБџн · на ТУ КкБППК'ь тело

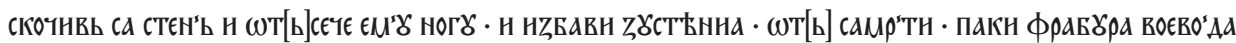

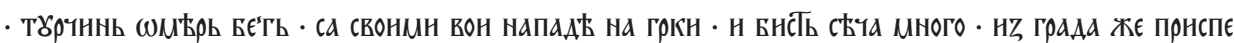

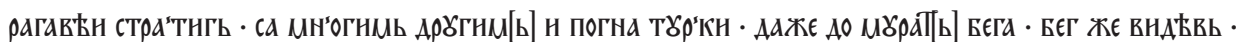

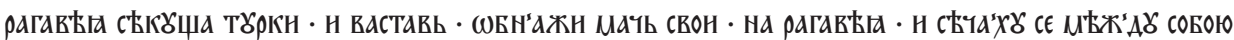

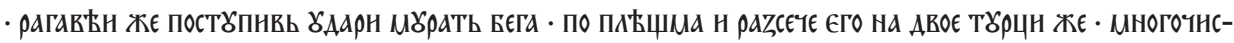

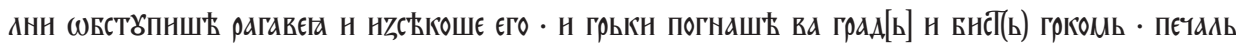

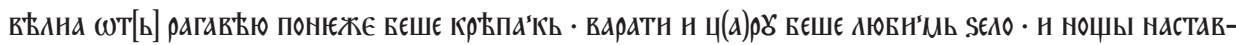

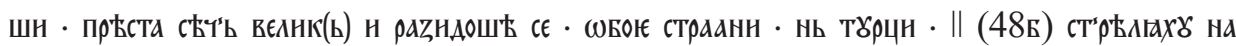

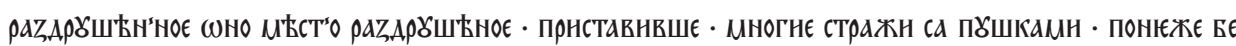

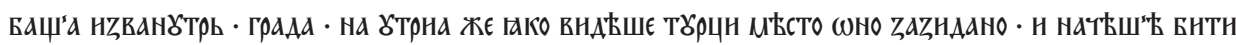

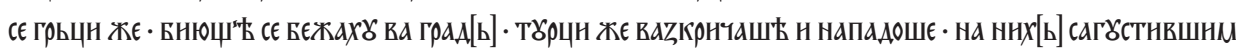

${ }^{10}$ Написано рецц. 


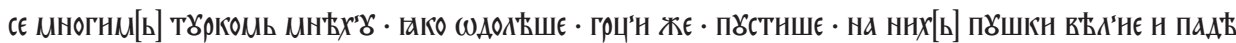

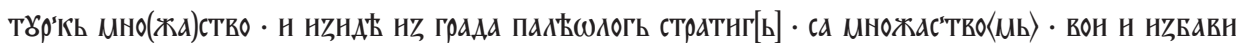

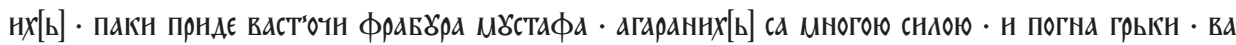

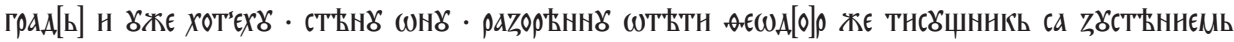

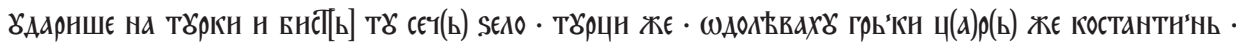

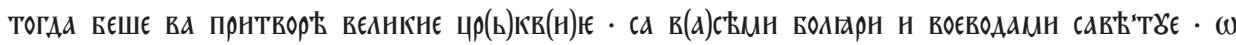

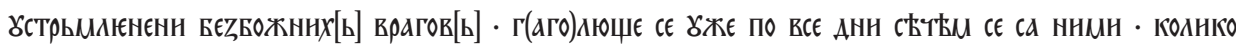

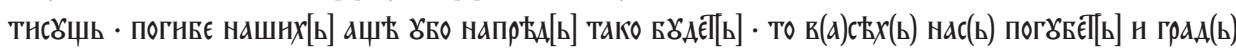

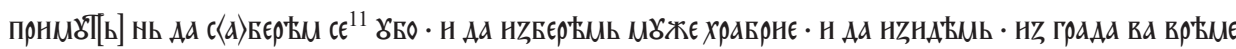

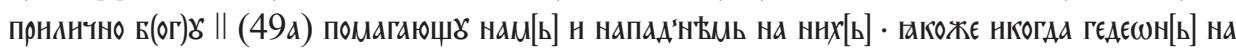

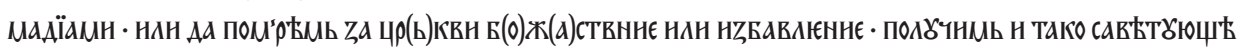

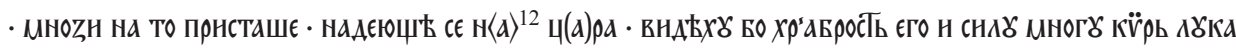

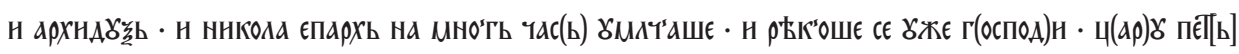

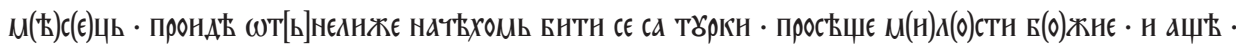

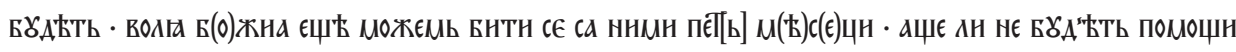

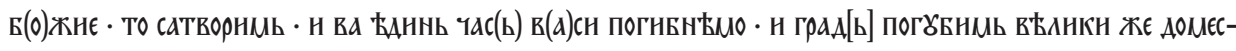

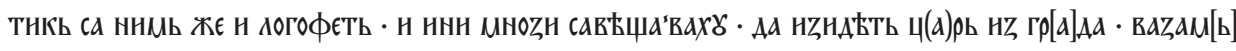
са совою • НZБранннк[[ ]

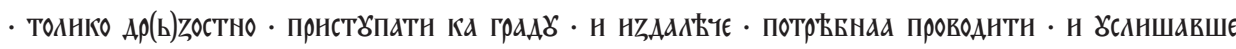

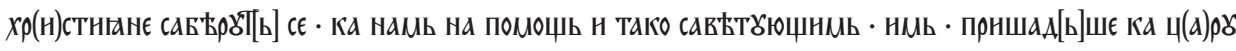

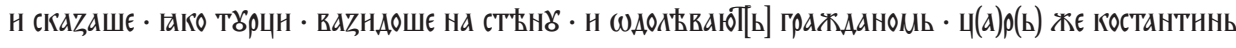

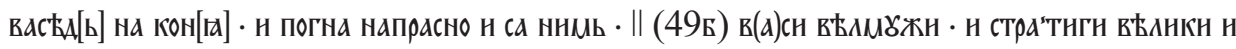

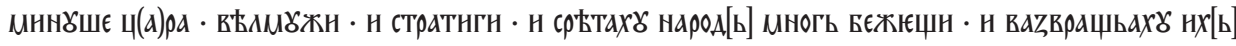

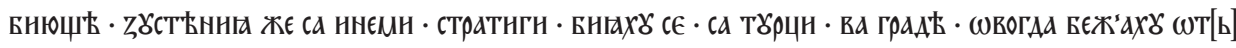

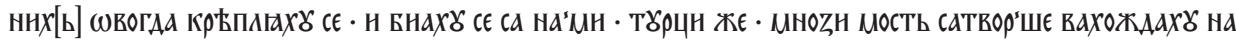

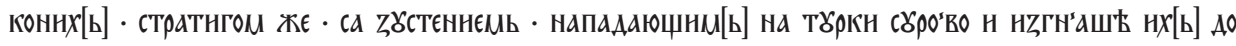

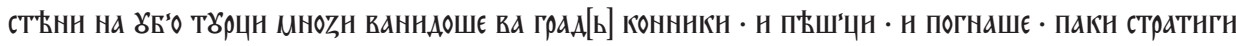

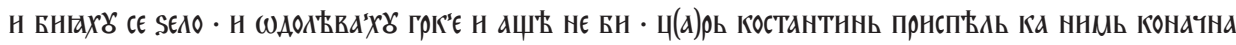

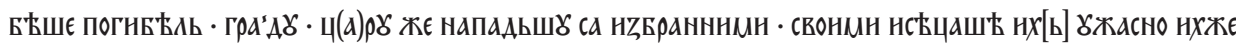

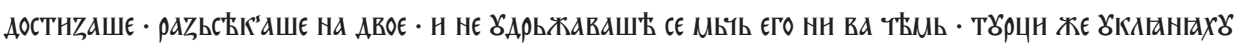

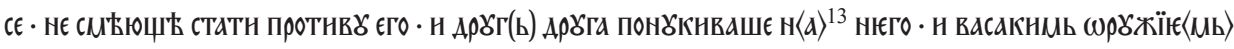

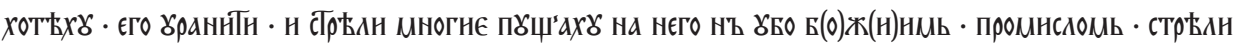

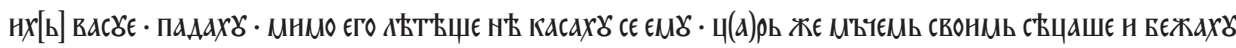

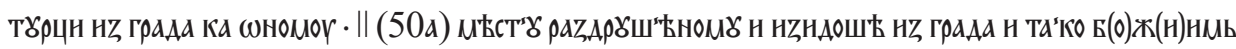

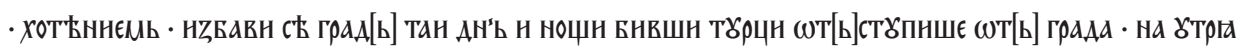

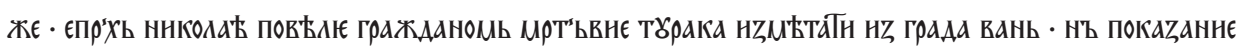

\footnotetext{
${ }^{11}$ Написано съьЂрєм сє.

${ }^{12}$ Написано нь.

${ }^{13}$ Написано нъ.
} 


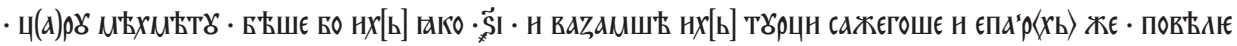

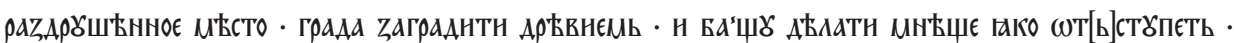

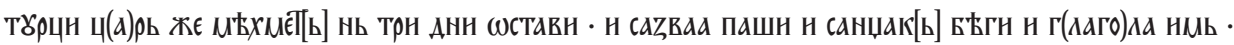

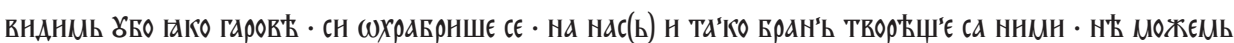

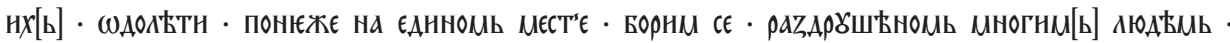

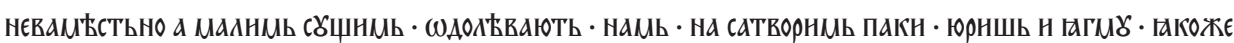

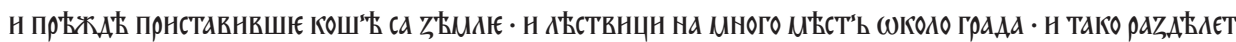

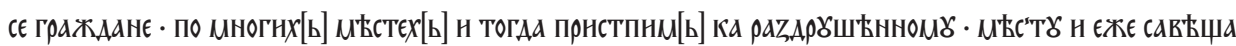

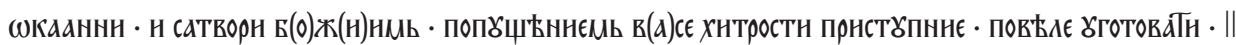

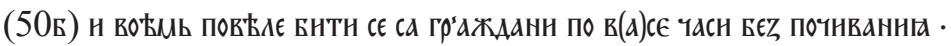

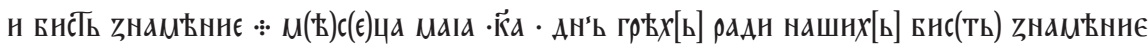

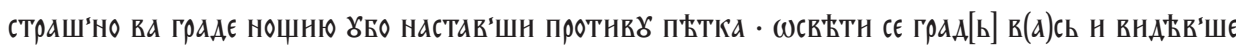

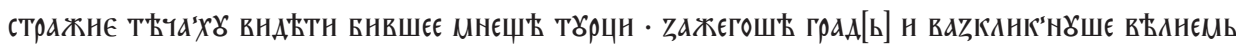

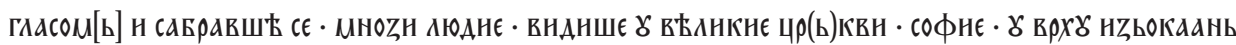
ПлаһћнУ -

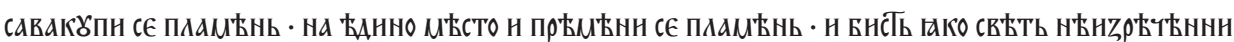

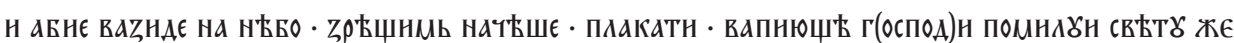

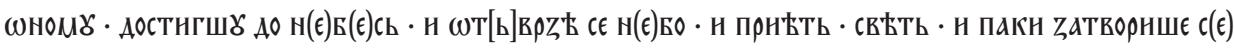

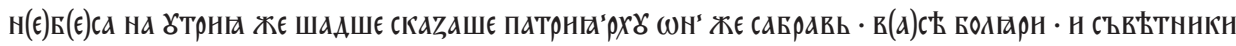

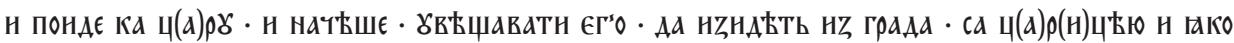

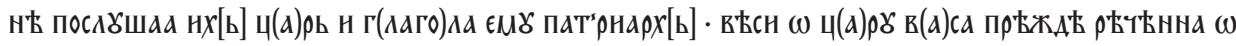

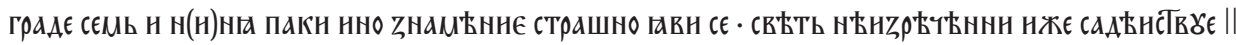

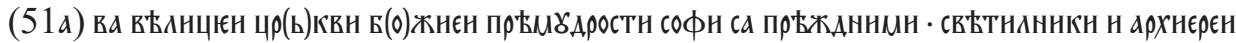

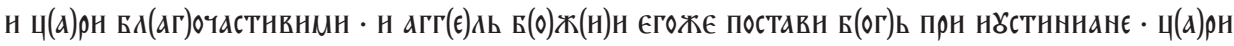

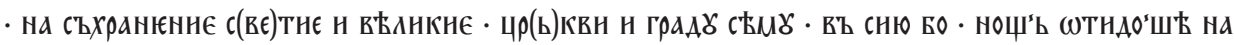

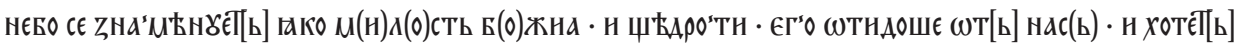

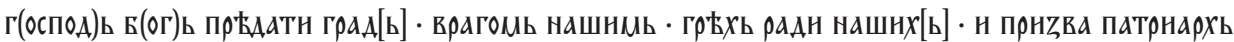

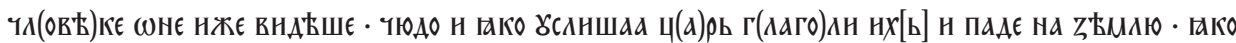

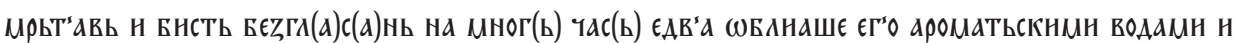

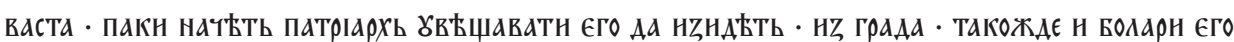

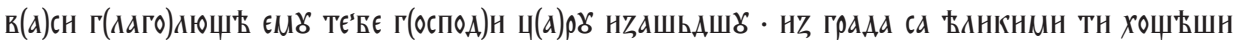

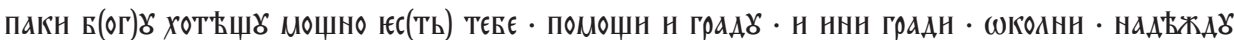

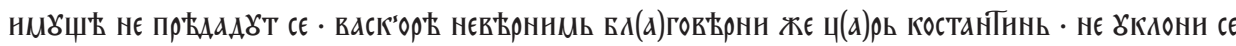

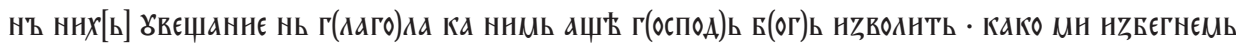

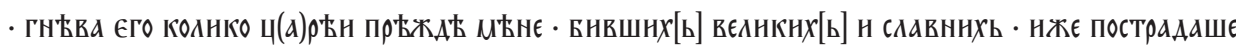

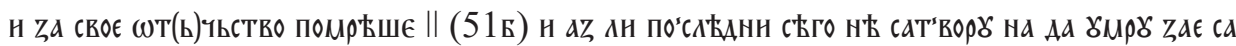

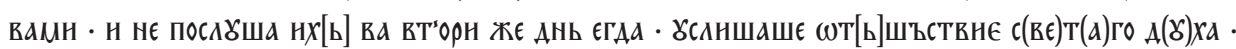

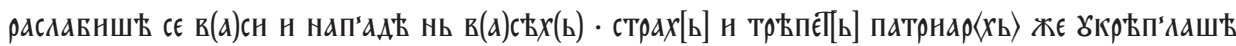
- нХ[ь] н бчашє нх[ь] не 


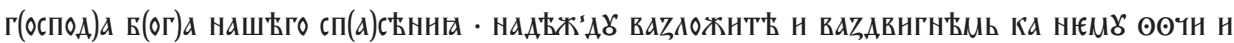

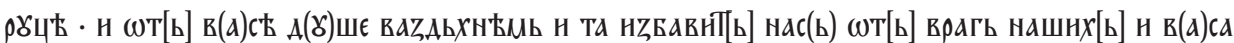

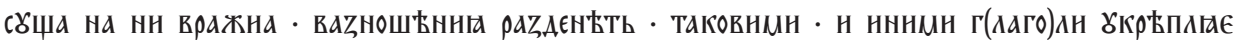

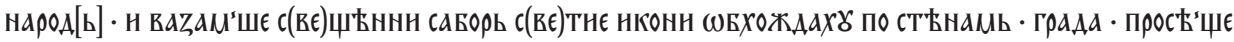

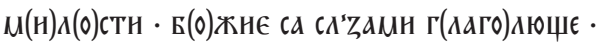

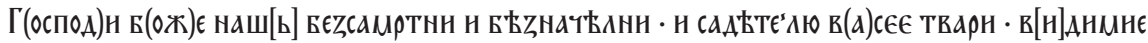

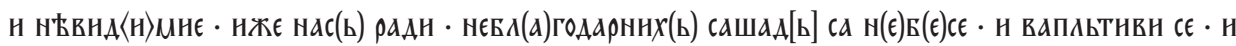

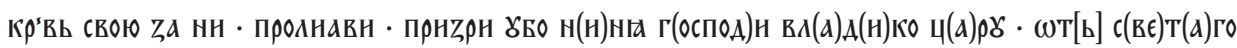

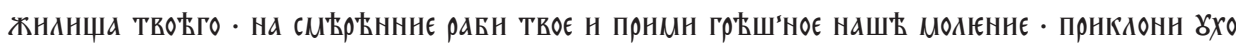

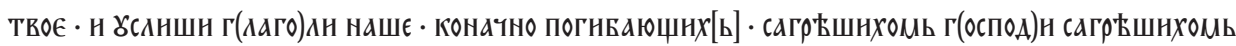

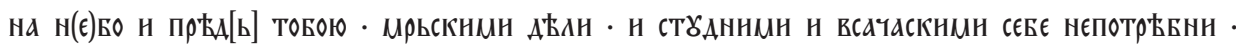

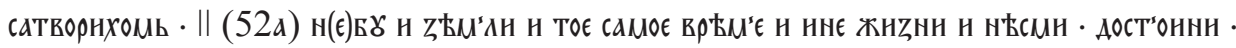
ваZ’РБТН на внсотУ Твою

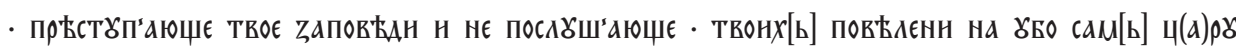

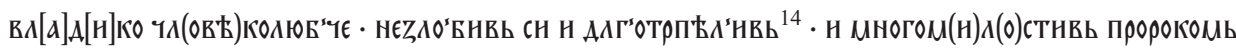

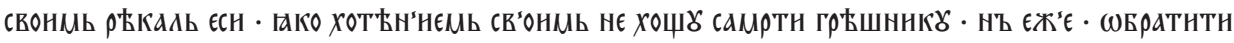

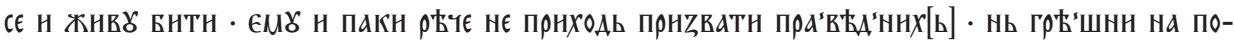

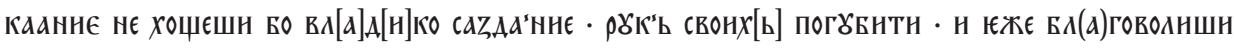

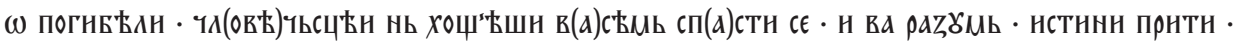

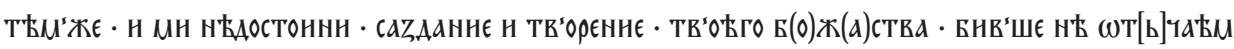

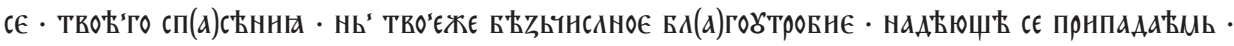

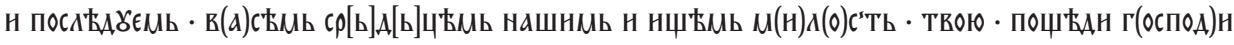

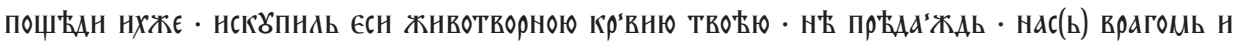

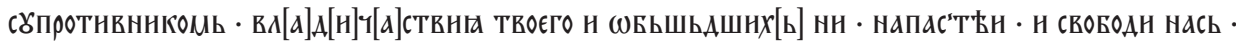

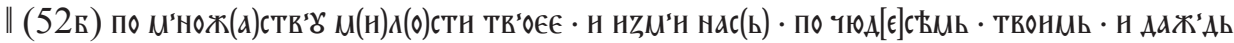

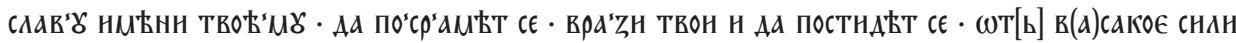

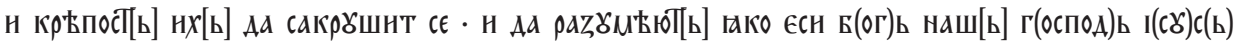
Х(рнсто)сь ва сзАавУ Б(о)гУ

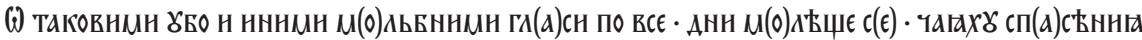

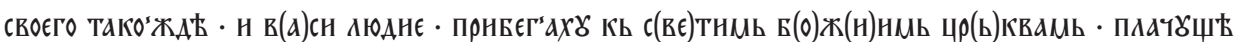

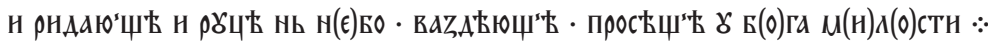

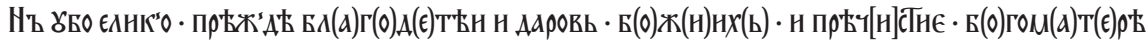

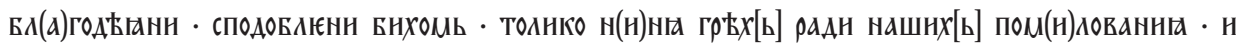

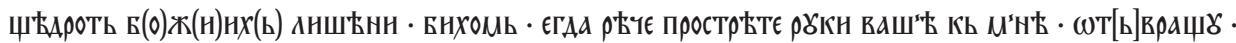

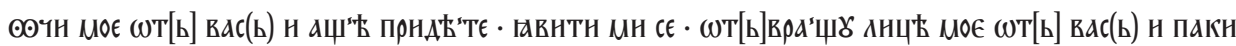

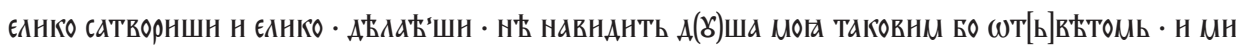

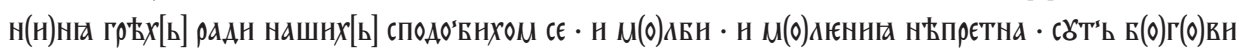

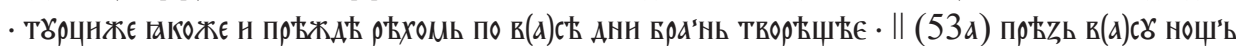

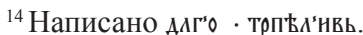


(

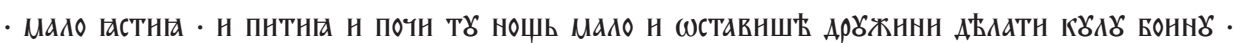

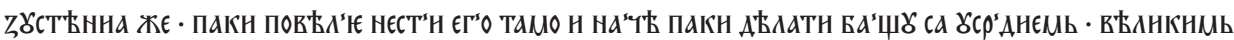
въ ·

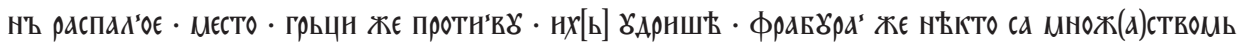

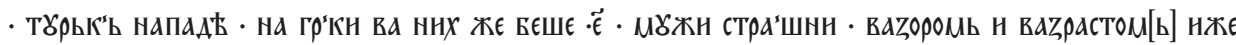

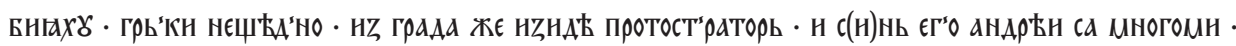

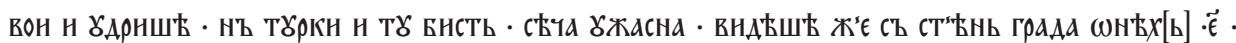

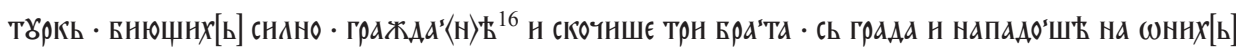

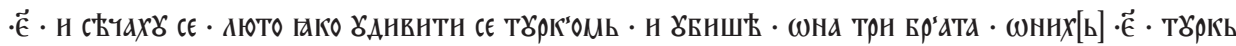

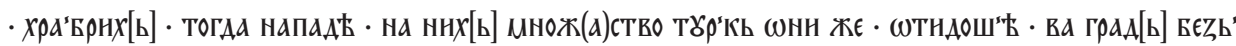

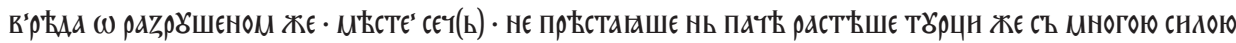

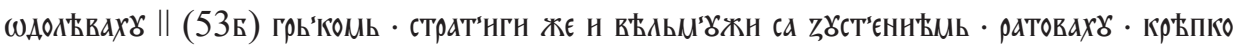
н тУ падБ цнож(а)ство

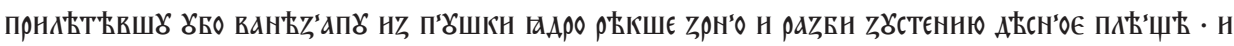

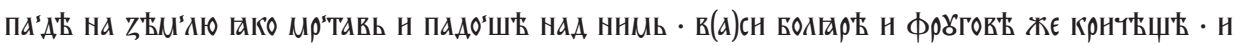

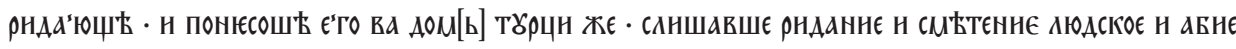

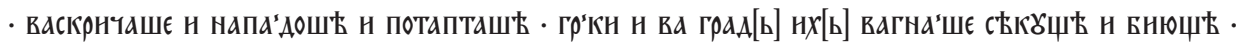

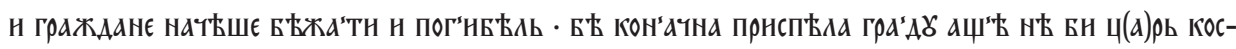

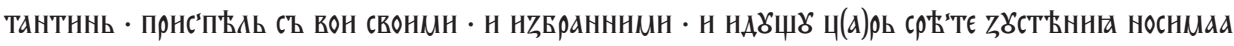

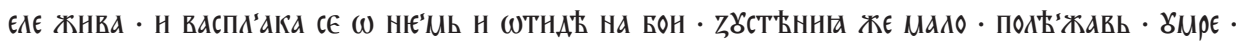

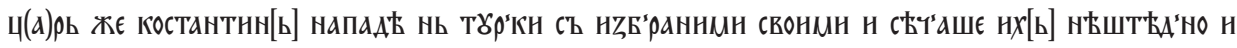

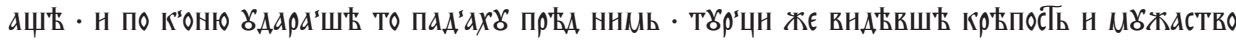

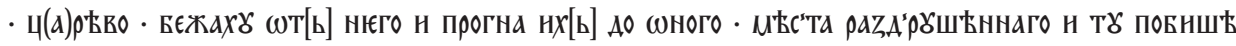

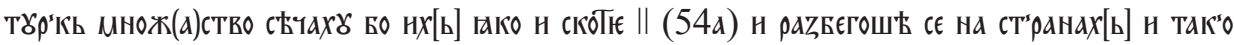

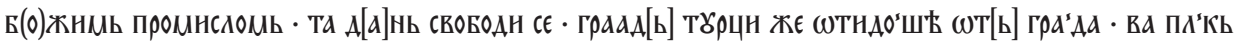

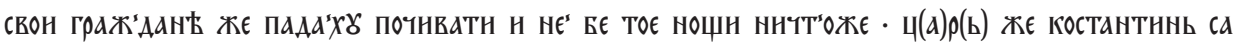

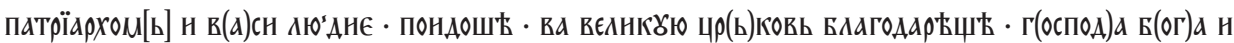

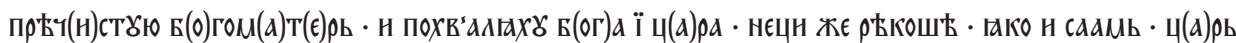

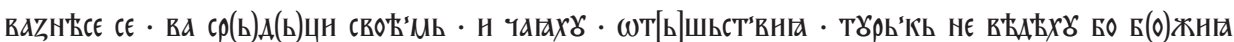

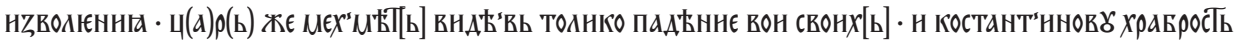

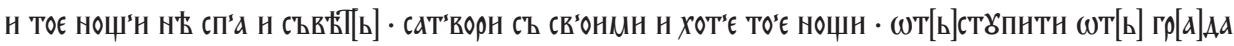

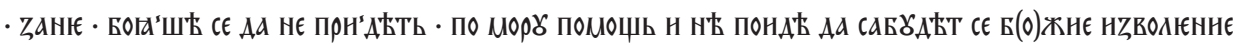

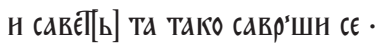

н БнСТ(ь) ннО ZНаМенне

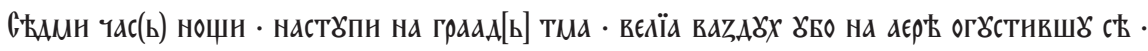

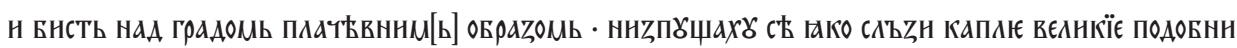

\footnotetext{
${ }^{15}$ Написано нь.

${ }^{16}$ Написано грджда'шь.
} 


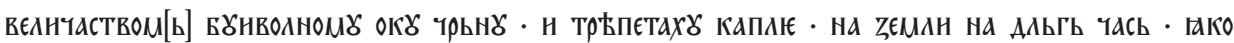

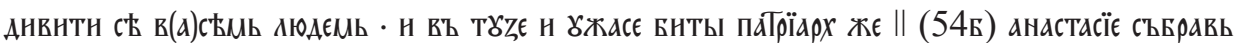

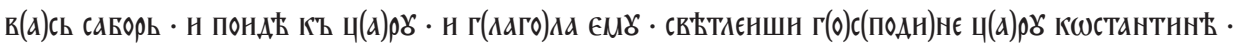

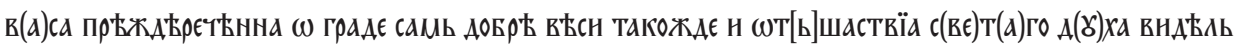

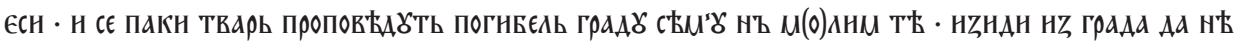

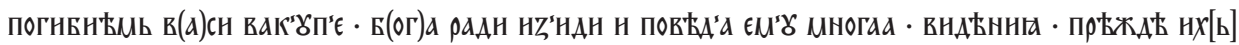

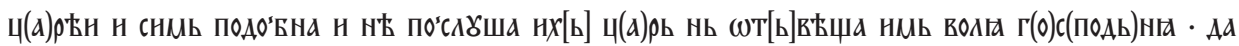

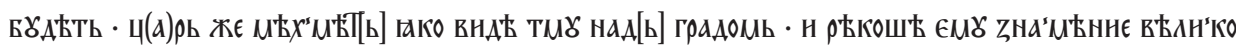

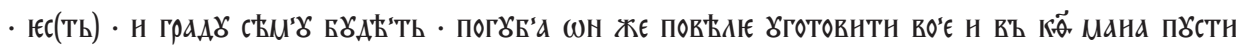

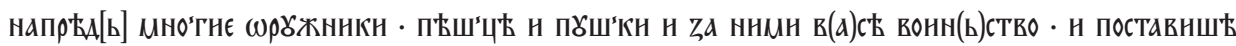

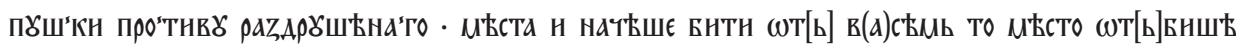
граждане

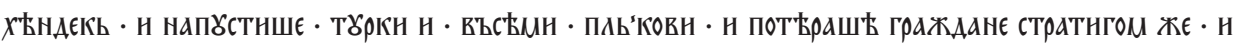

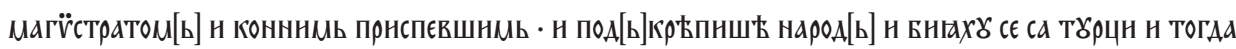

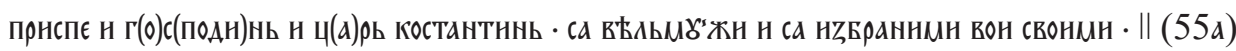

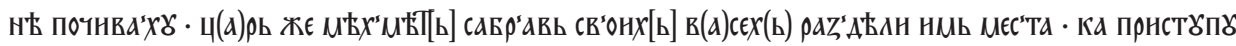
ПоставН ӘБ'0 корачь Бе

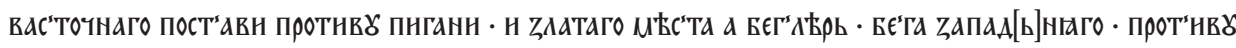

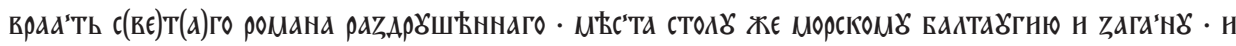
(БьстУПншБ оБє странн

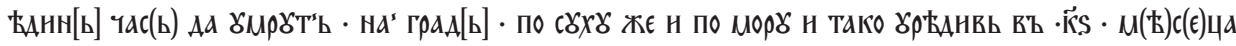

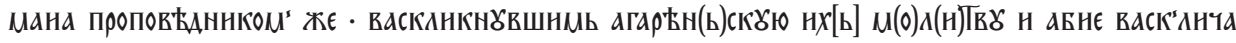

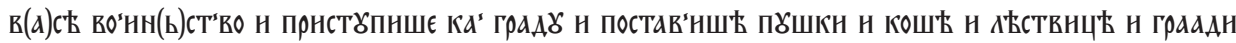

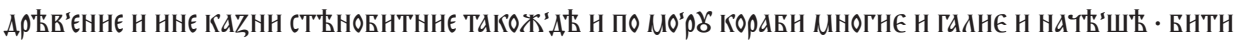

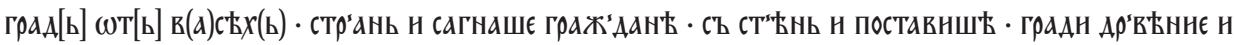

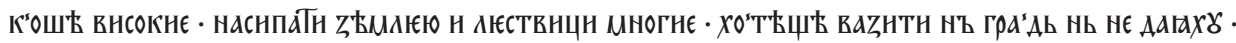

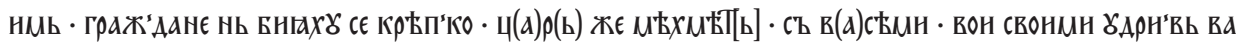

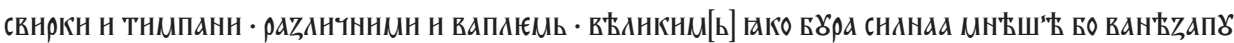

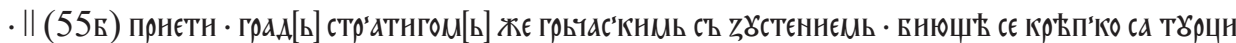

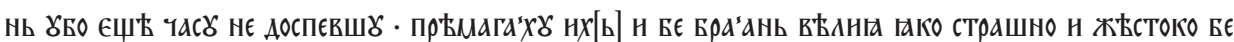

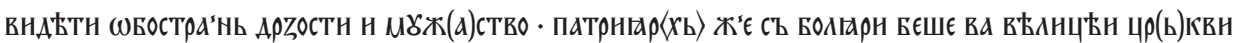

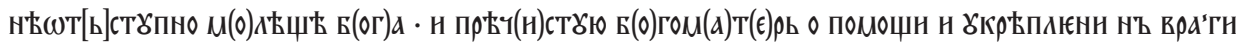

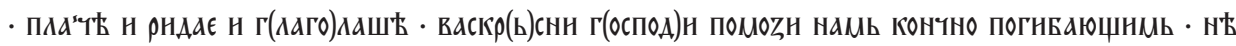

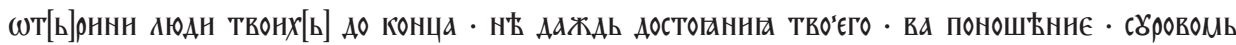

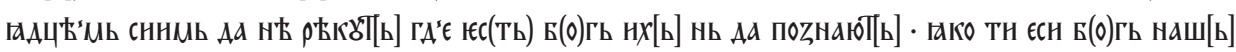

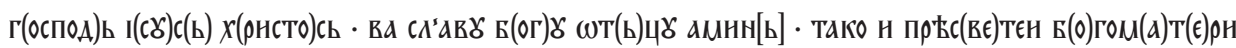
ваZГАаш'ающ' -

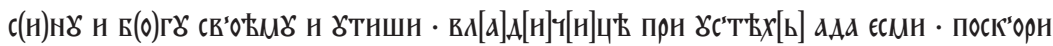

\footnotetext{
${ }^{17}$ Написано подл'ать.
} 


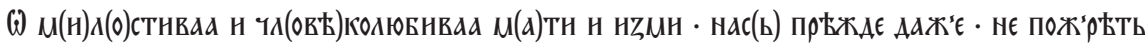

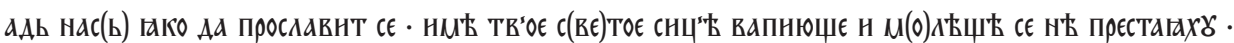

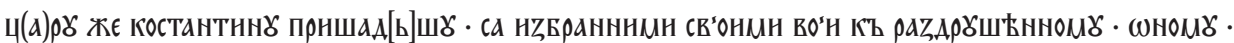

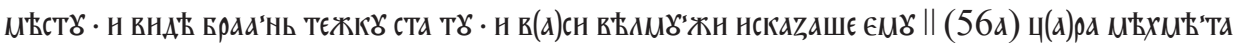

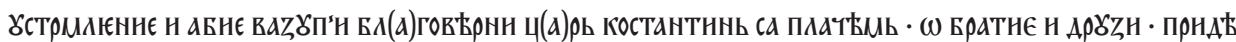
врБМє -

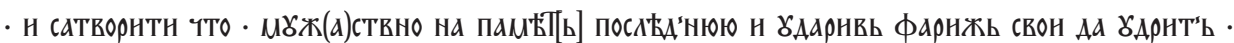

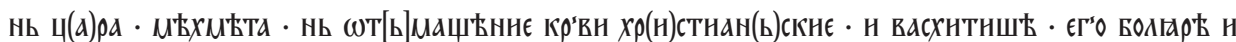

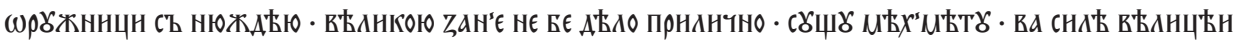

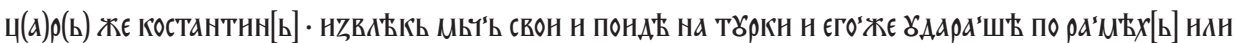

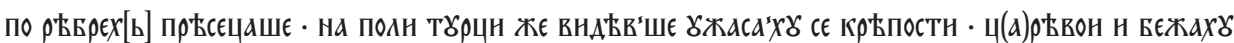

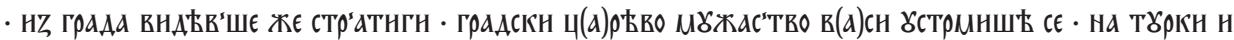

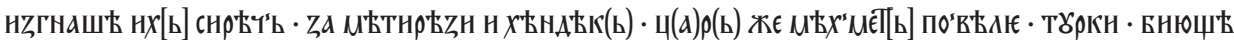

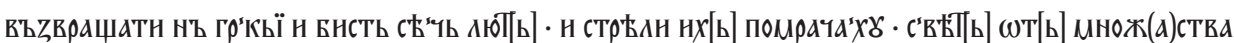

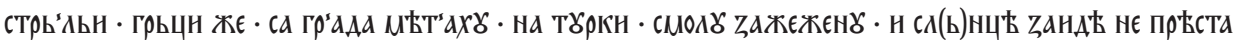

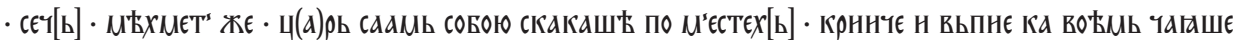

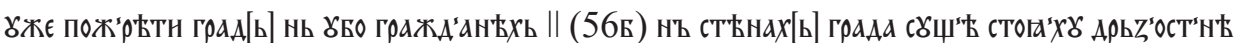

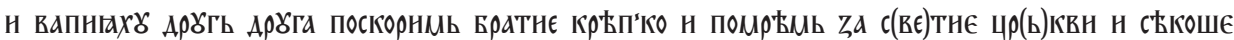

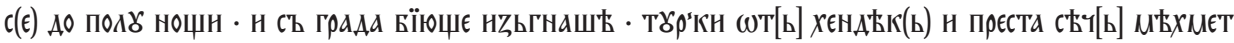

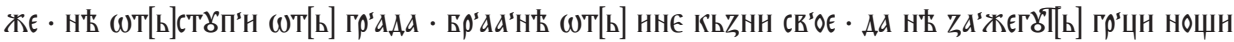

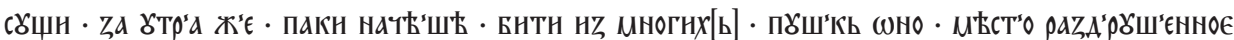

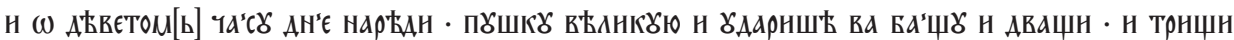

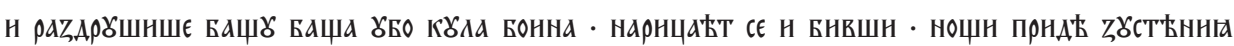

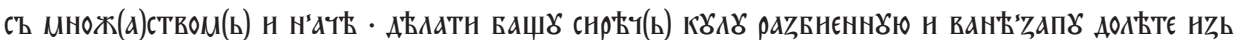

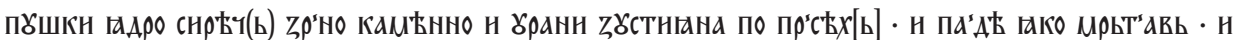

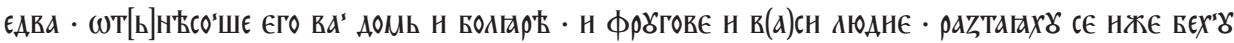

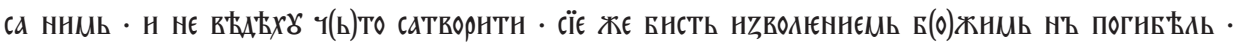

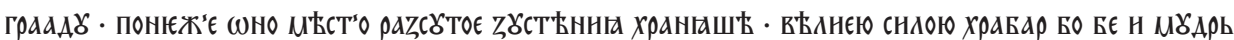

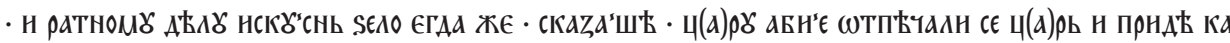

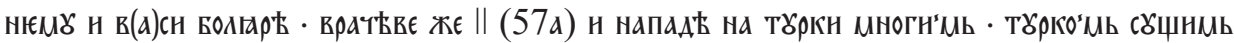

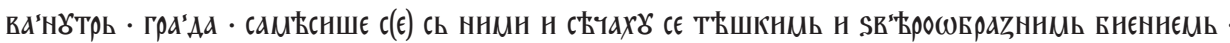

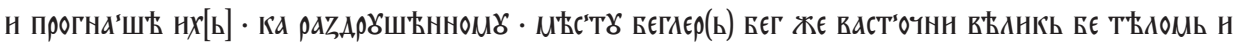

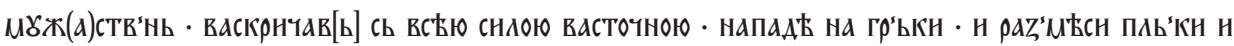

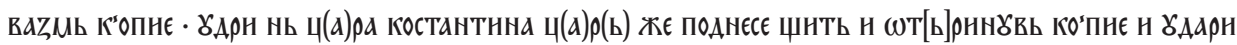

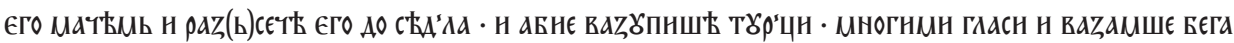

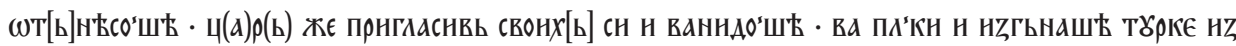

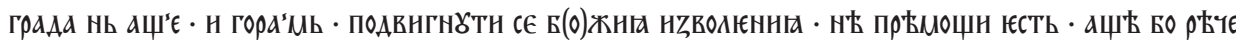

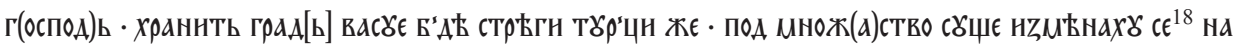

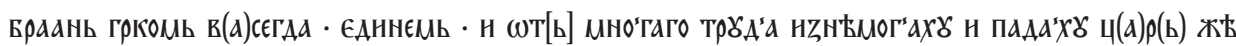

\footnotetext{
${ }^{18}$ Написано нzнzмњнаху сє.
} 


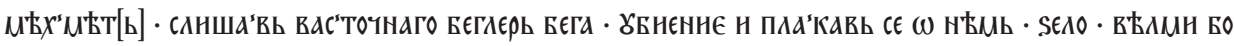

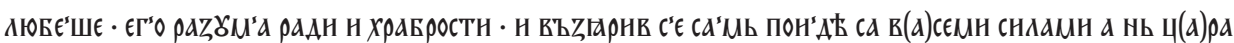

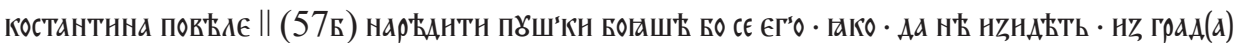

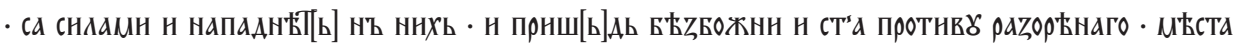
н повБАє Бні|[н] нZ ПбШ'Кь да

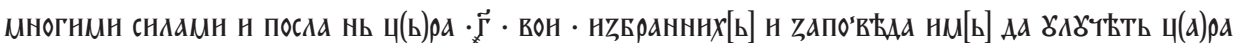

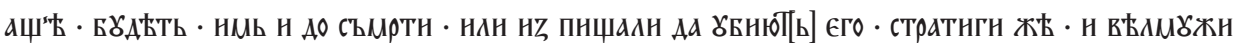

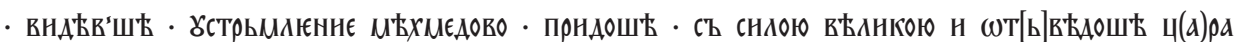

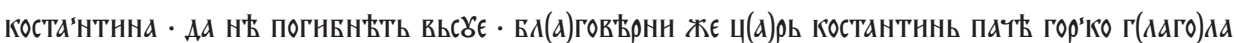

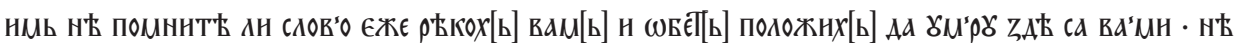

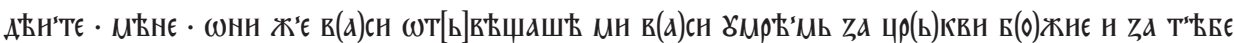

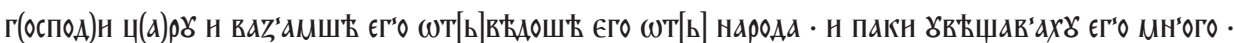

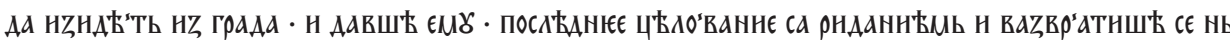

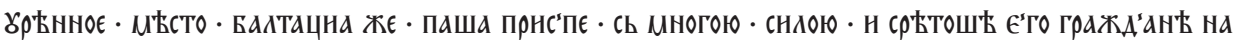

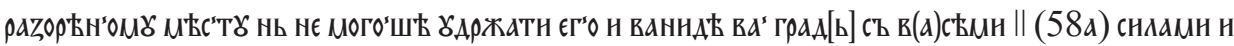

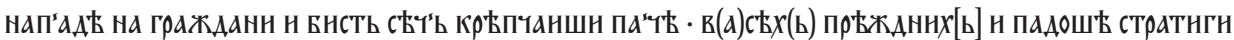

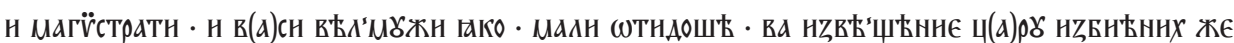

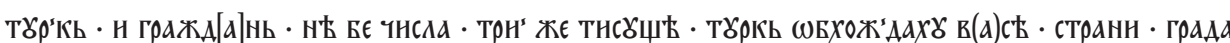

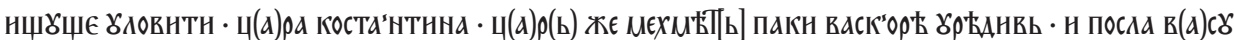

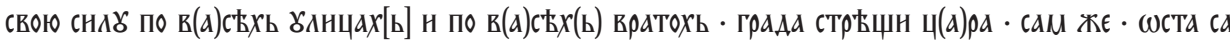

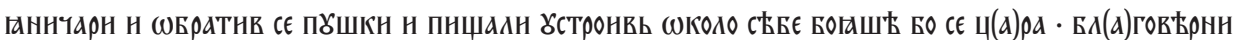

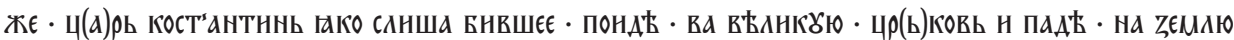

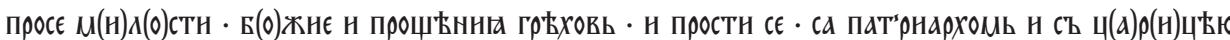

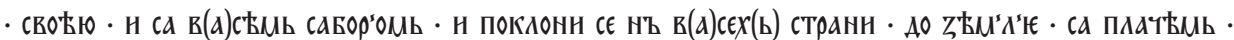

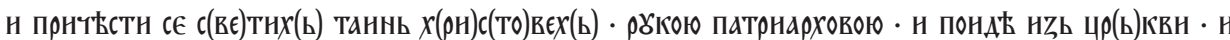

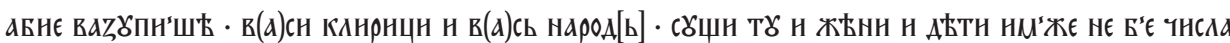

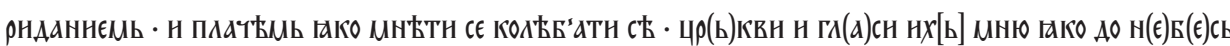

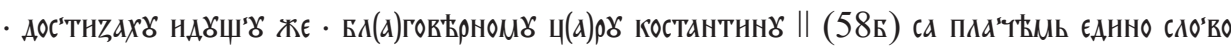

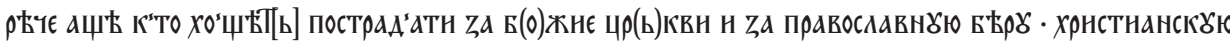

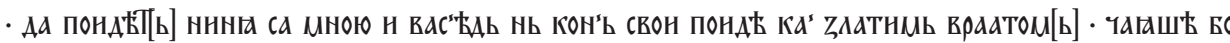

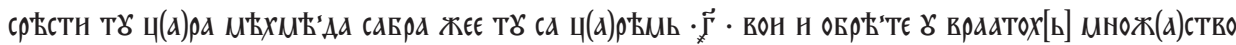

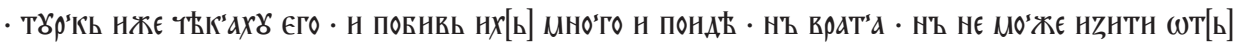

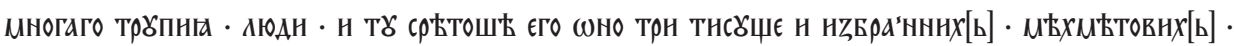

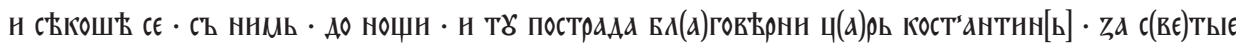

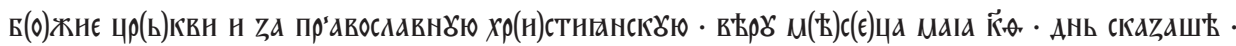

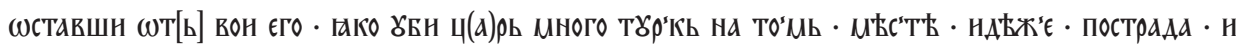

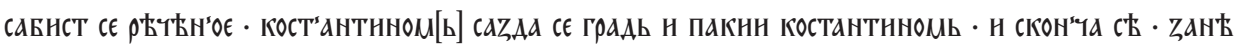

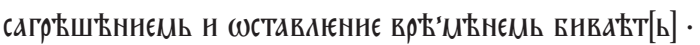

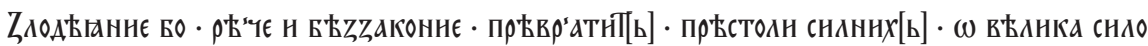

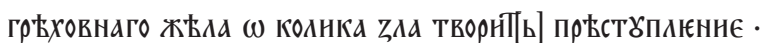




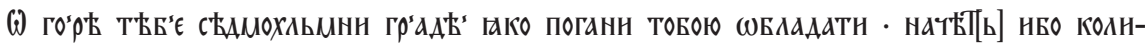

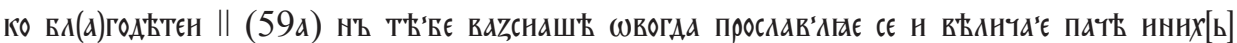

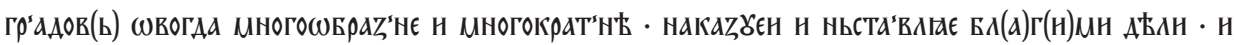

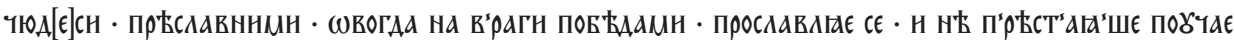

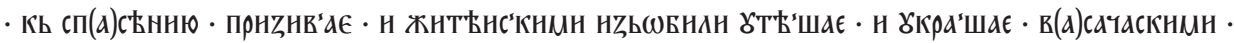

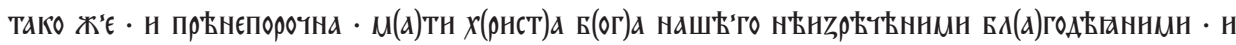

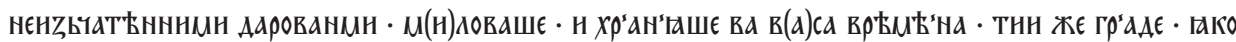

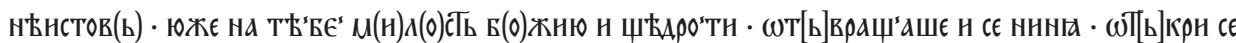

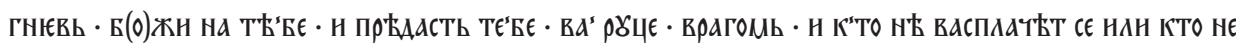

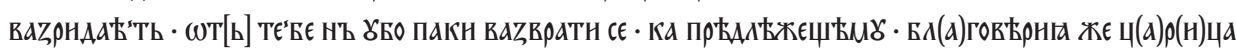

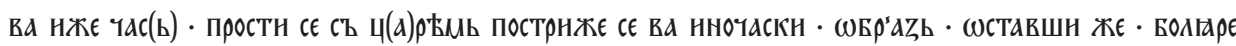

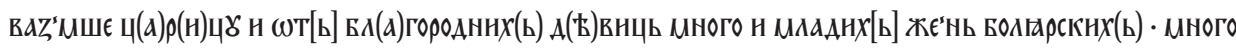

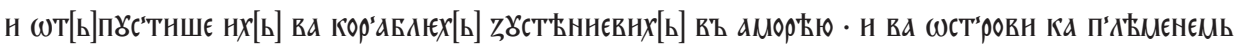
- Граждане же -

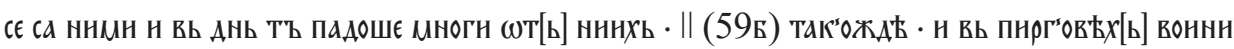

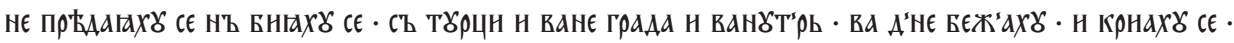

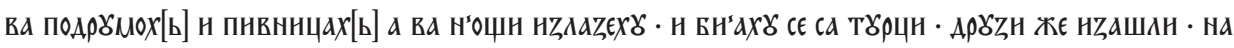

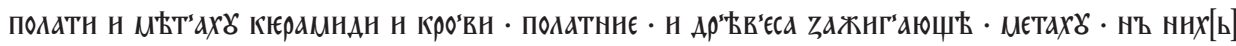

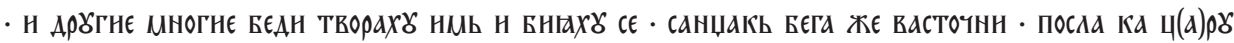

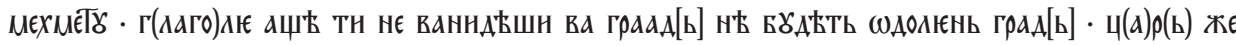

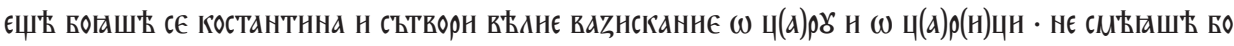

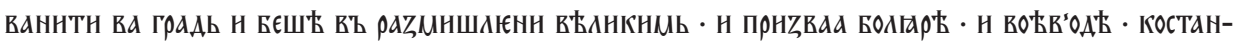

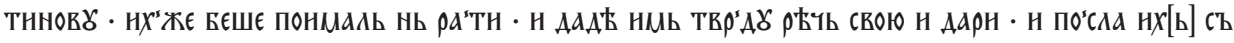

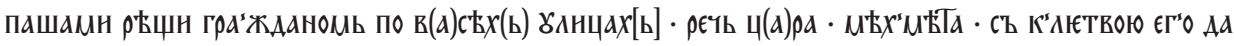

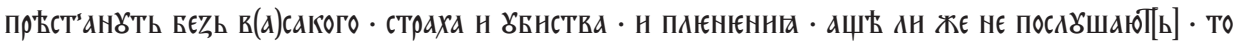

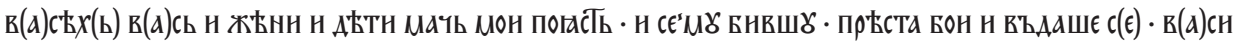

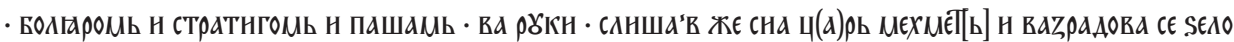

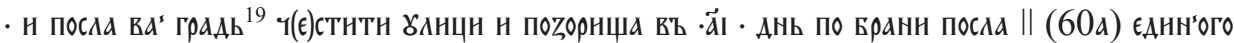

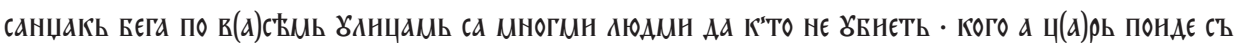

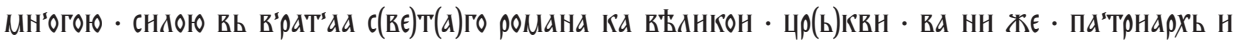

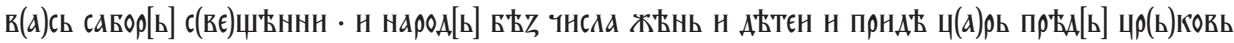

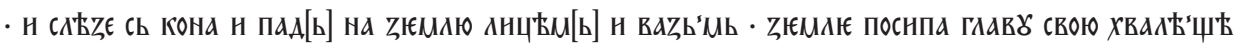

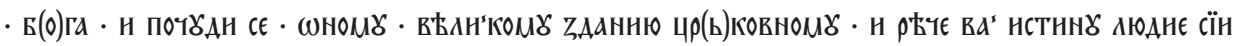

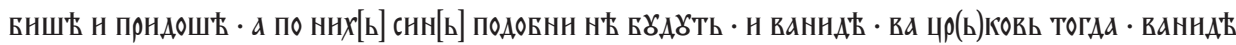

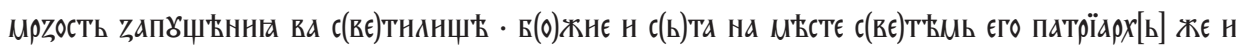

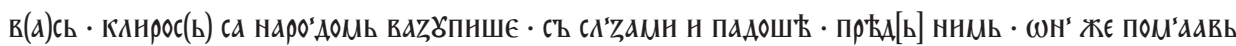

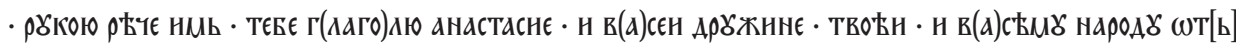

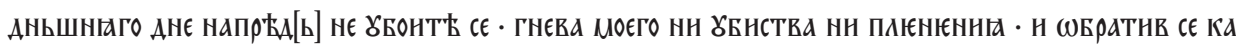

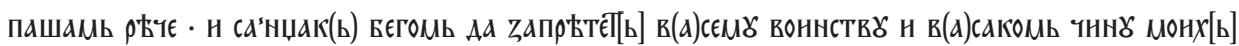

\footnotetext{
${ }^{19}$ Написано свакако грешком најпре ва араф[ь], а онда исправно вд градь.
} 


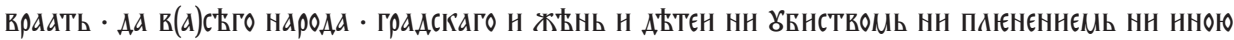

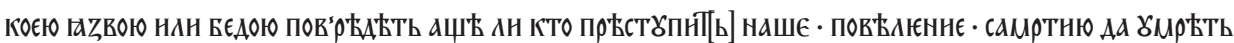

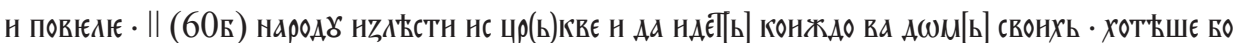

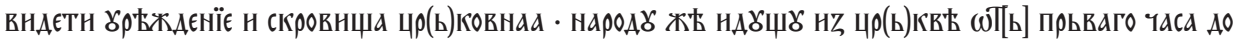

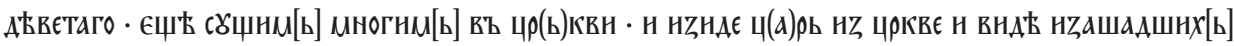

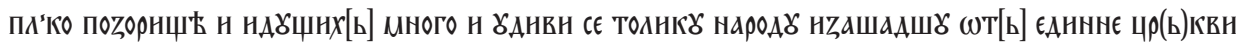

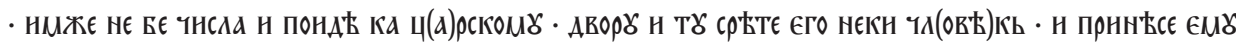

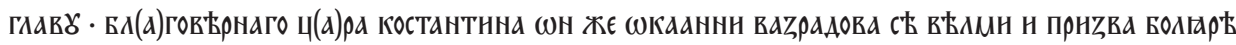

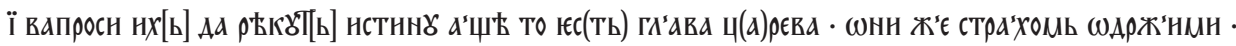

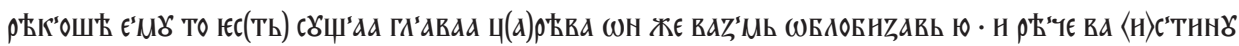

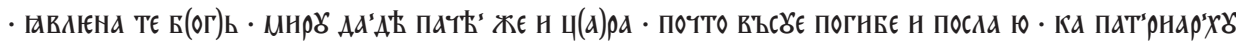
Аd

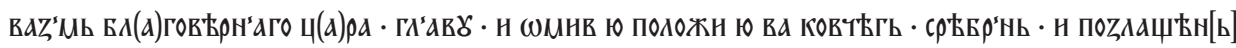

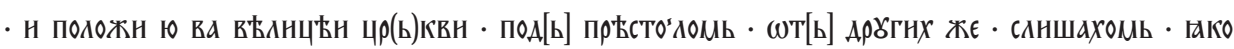

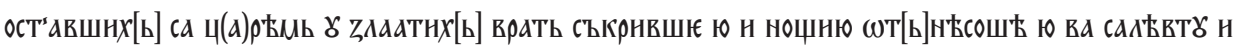

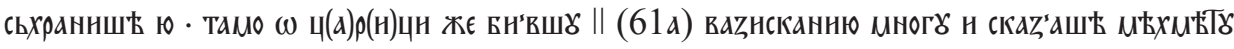

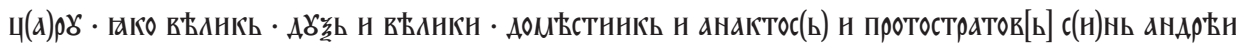

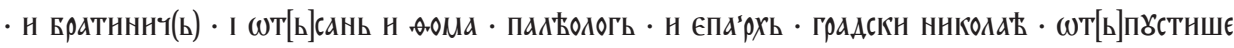

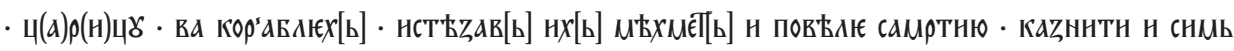

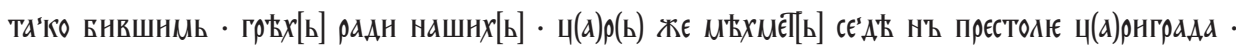

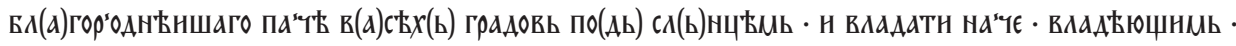

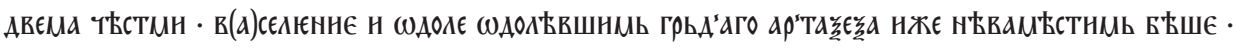

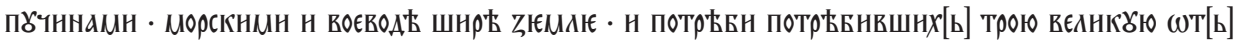

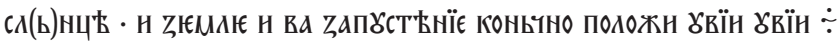

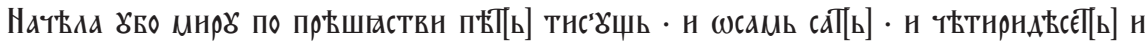

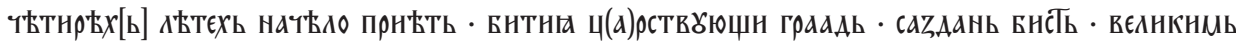

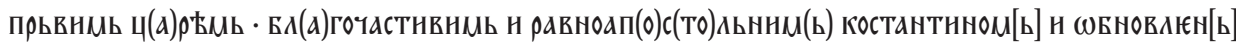
Бнсть $\omega$ Т[ь] с(вє)тЫХ(ь)

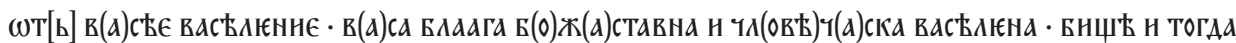

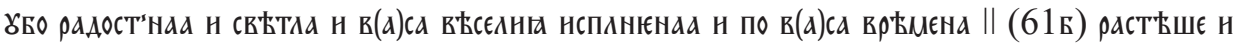

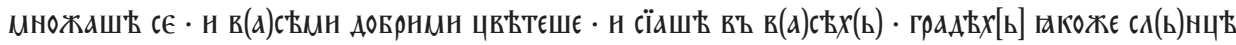

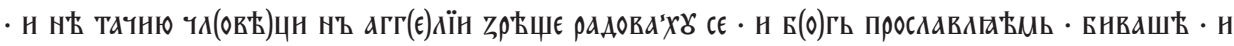

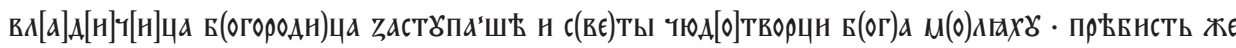
растїн н разьшнрає сє - $\omega$ Т[Ь] прваго ц(а)ра костантнна $九$ БТЬ

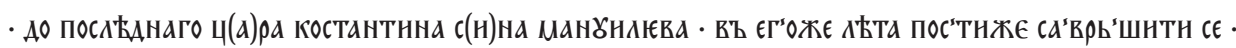

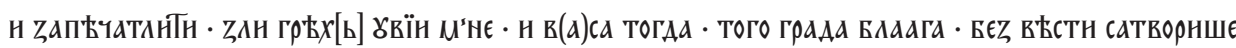

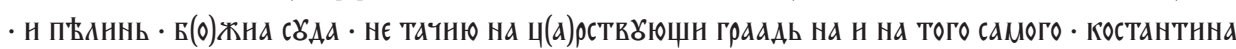

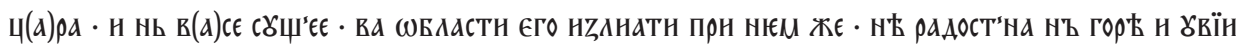

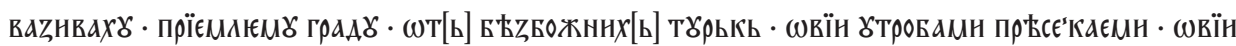




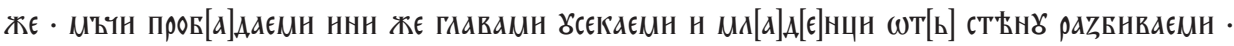

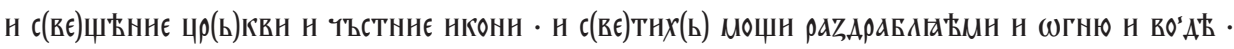

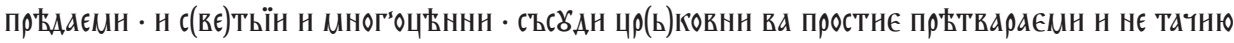

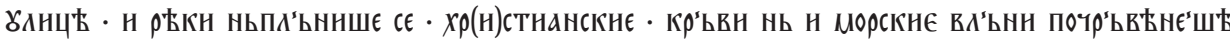

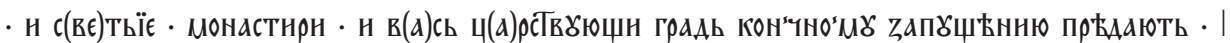

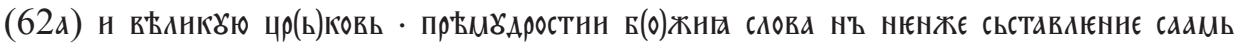

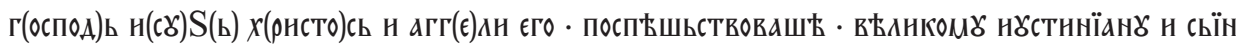

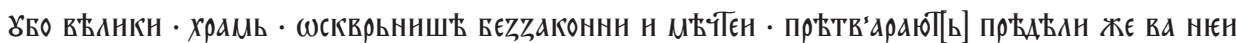

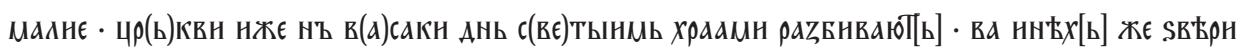

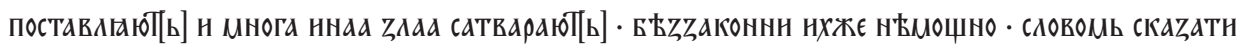

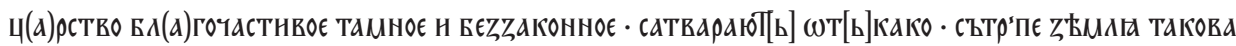

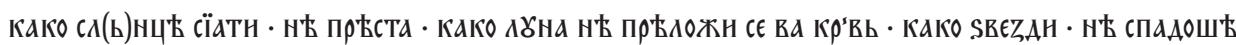
гако лнСТвне •

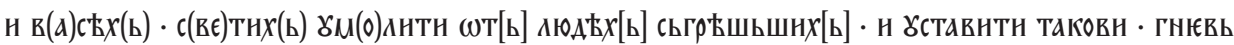

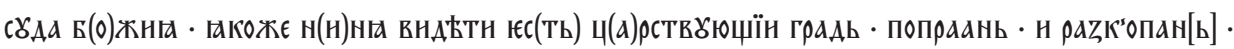

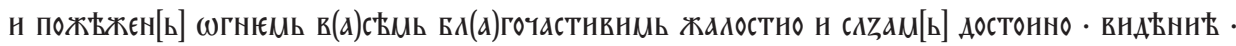

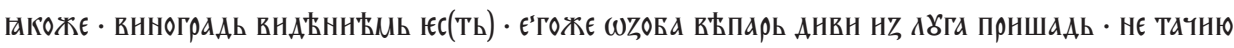

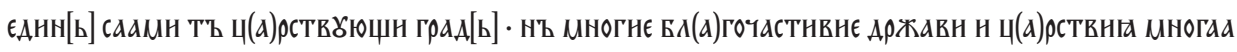

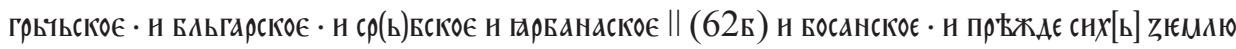

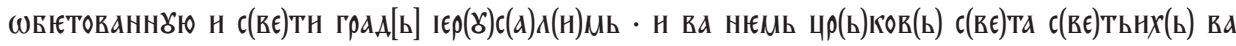

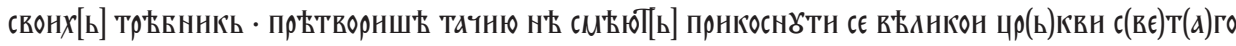

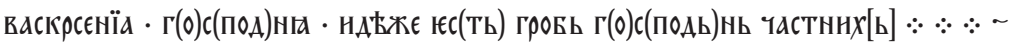

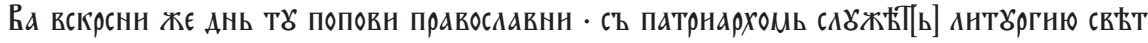
Же Н( $(\epsilon)$ Б $(\epsilon)$ сна

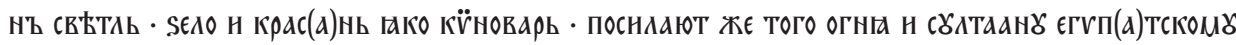

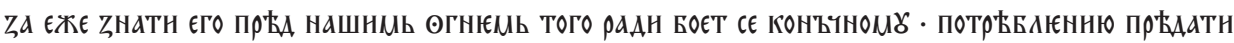

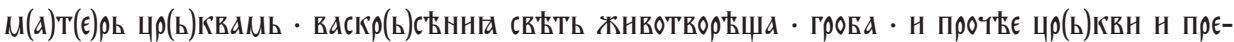

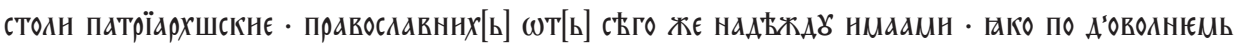

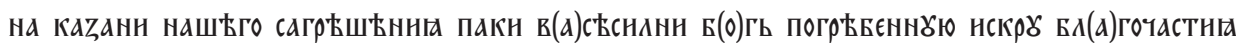

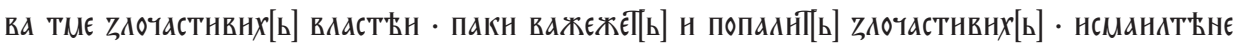

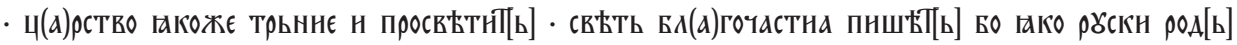

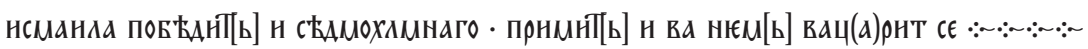

